\title{
Respiratory Function of the Placenta as Determined with Carbon Monoxide in Sheep and Dogs*
}

\author{
Lawrence D. Longo, † Gordon G. Power, † and Robert E. Forster il \\ (From the Department of Physiology, Graduate Division, and the Department of Obstetrics and Gynecology, \\ School of Medicine, University of Pennsylvania, Philadelphia, Pa.)
}

Summary. A technique is described for studying the respiratory function of the placenta using carbon monoxide, a gas whose exchange across the placenta between the maternal and fetal circulations is limited by diffusion rather than blood flow.

During the steady state before the introduction of $\mathrm{CO}$, the normal concentration of carboxyhemoglobin in the ewe, $[\mathrm{COHb}]_{\mathrm{M}}$, is approximately $0.90 \%$, and that in the fetus is $2.9 \%$, the ratio $[\mathrm{COHb}]_{\mathrm{F}} /[\mathrm{COHb}]_{\mathrm{M}}$ being 3.2. In dogs the corresponding values are $1.9 \%, 4.8 \%$, and $2.4 \%$.

After the introduction of $\mathrm{CO}$ into the mother animal, $\mathrm{CO}$ diffused across the placenta slowly with an equilibration half-time of approximately 2 hours.

The average carbon monoxide diffusing capacity $\left(\mathrm{DP}_{\mathrm{CO}}\right)$ of the placenta during maternal to fetal exchange was $0.54 \mathrm{ml}$ per (minute $\times \mathrm{mm} \mathrm{Hg} \times \mathrm{kg}$ fetal weight) $(\mathrm{SD} \pm 0.13)$ in sheep and $0.57 \mathrm{ml}$ per (minute $\times \mathrm{mm} \mathrm{Hg} \times \mathrm{kg})(\mathrm{SD} \pm 0.18)$ in dogs.

The fetal to maternal placental diffusing capacity in two sheep was $0.54 \mathrm{ml}$ per (minute $\times \mathrm{mm} \mathbf{H g} \times \mathbf{~ k g}$ ).

Calculations considering the relative rates of reaction of $\mathrm{O}_{2}$ and $\mathrm{CO}$ with red cell hemoglobin and the relative rates of diffusion of the two gases suggest that the true $\mathrm{DP}_{\mathrm{O} 2}$ should be about 1.2 to 2 times greater than the $\mathrm{DP}_{\mathrm{CO}}$ or 0.65 to $1.1 \mathrm{per}$ (minute $\times \mathrm{mm} \mathrm{Hg} \times \mathrm{kg}$ ). This is about 5 times greater than the reported value of $\mathrm{DP}_{2}$ calculated from measurements of $\mathrm{PO}_{2}$ in the mixed uterine and umbilical venous blood. With a diffusing capacity of this magnitude the maternal and fetal placental end capillary $\mathrm{Po}_{2}$ would approach equilibrium, becoming too small to measure, and the calculation of $\mathrm{DP}_{\mathrm{O} 2}$ would be unreliable. We suggest that the apparent end capillary $\mathrm{Po}_{2}$ gradients of 15 to $20 \mathrm{~mm} \mathrm{Hg}$, obtained from sampling uterine and umbilical venous blood, result from a combination of uneven distribution of maternal and fetal placental blood flow and from placental oxygen consumption.

\section{Introduction}

A convenient measure of the adequacy of respiratory gas exchange is diffusing capacity,

* Submitted for publication May 16, 1966; accepted January 27, 1967.

This study was presented in part at the Annual Meeting of the American Society for Clinical Investigation, Atlantic City, N. J., May 3, 1965 . It was supported by grant HD-1860 from the National Institute of Child Health and Human Development and by grants from the Life Insurance Medical Research Fund and the Josiah Macy, Jr., Foundation. which is defined as the milliliters of gas crossing the respiratory membrane per minute per millimeter of mercury of partial pressure gradient. The placental diffusing capacity for oxygen has been calculated by several investigators (1-4); although the results are fairly uniform, there is,

† Postdoctoral fellow of the National Institutes of Health.

Address requests for reprints to Dr. Lawrence D. Longo, Dept. of Physiology, Graduate Division, School of Medicine, University of Pennsylvania, Philadelphia, $\mathrm{Pa}$. 19104. 
for the following reasons, considerable uncertainty as to its validity as a measure of placental exchange: 1) Placental oxygen consumption has been shown to be a considerable fraction of the total $\mathrm{O}_{2}$ exchanged $(5,6)$, and we have no way of determining how this affects the equilibration of maternal and fetal placental capillary $\mathrm{Po}_{2}$. 2) Blood bypassing gas exchanging vessels through shunts, and uneven distribution of maternal and fetal placental blood flow, will affect the value of $\mathrm{PO}_{2}$ in the mixed uterine and umbilical vein blood making it impossible to calculate the true end capillary $\mathrm{Po}_{2}$ values (7). 3) In addition, there is no agreement as to the spatial relation of blood flow in maternal and fetal placental capillaries, thus making meaningless any calculations of the mean capillary $\mathrm{Po}_{2}$ values or the mean maternalfetal placental $\mathrm{Po}_{2}$ gradients.

In the early part of this century there was a similar question as to the true oxygen partial pressure gradients from pulmonary alveoli to the pulmonary capillaries. Carbon monoxide exchanges proved to be useful in resolving this controversy (8-10), and we thought that they might also be of value in estimating the mean maternalfetal $\mathrm{Po}_{2}$ difference. Therefore in the present study we have measured the placental diffusing capacity of $\mathrm{CO}$ from which we calculated the corresponding $\mathrm{O}_{2}$ diffusing capacity and the mean maternal-fetal $\mathrm{PO}_{2}$ difference. The advantages of $\mathrm{CO}$ for the study of placental gas exchange are these: 1) The fetal uptake of $\mathrm{CO}$ can be accurately measured, since $\mathrm{CO}$ is not consumed by the uterine or placental tissue in appreciable amounts. 2) In contrast to the maternal and fetal $\mathrm{O}_{2}$ partial pressures, uneven distribution of flow does not significantly influence the amount of $\mathrm{CO}$ exchanged or the mean partial pressure gradient. 3) The maternal-fetal $\mathrm{CO}$ partial pressure gradient is approximately 3 to 5 times the partial pressure of $\mathrm{CO}$ in fetal blood. Except for several studies of carbon monoxide poisoning in pregnancy (11-14) CO has not been previously employed to study placental exchange.

\section{Methods}

The principle of our method was to place a pregnant experimental animal on a closed-circuit rebreathing apparatus into which $\mathrm{CO}$ was introduced. At appropriate time intervals samples of maternal and fetal arterial and venous
TABLE I

Vital statistics

\begin{tabular}{|c|c|c|c|c|}
\hline \multicolumn{2}{|c|}{ Animal } & $\begin{array}{c}\text { Maternal } \\
\text { weight }\end{array}$ & $\begin{array}{l}\text { No. of } \\
\text { fetuses }\end{array}$ & $\begin{array}{c}\text { Fetal } \\
\text { weight }\end{array}$ \\
\hline Dog & $\begin{array}{r}7 \\
9 \\
10 \\
11 \\
12\end{array}$ & $\begin{array}{l}16.8 \\
11.4 \\
11.8 \\
24.1 \\
10.0\end{array}$ & $\begin{array}{r}4 \\
4 \\
3 \\
10 \\
8\end{array}$ & $\begin{array}{l}0.24 \\
0.19 \\
0.25 \\
0.20 \\
0.11\end{array}$ \\
\hline Sheep & $\begin{array}{r}1 \\
2 \\
3 \\
4 \\
5 \\
6 \\
7 \\
8 \\
9 \\
11\end{array}$ & $\begin{array}{l}72 \\
73 \\
70 \\
50 \\
70 \\
55 \\
57 \\
43 \\
67 \\
48\end{array}$ & $\begin{array}{l}2 \\
2 \\
1 \\
2 \\
2\end{array}$ & $\begin{array}{c}3.9,4.3 \\
2.4,2.6 \\
2.4 \\
3.7,4.0 \\
1.9,2.0\end{array}$ \\
\hline
\end{tabular}

blood were taken and analyzed for $\mathrm{CO}, \mathrm{O}_{2}$, and $\mathrm{CO}_{2}$ content, $\mathrm{Po}_{2}, \mathrm{pH}$, and hemoglobin concentration.

Successful studies were carried out on five near-term pregnant mongrel dogs and ten near-term crossbred pregnant ewes (Table I). The dogs were anesthetized with sodium pentobarbital (20 $\mathrm{mg}$ per $\mathrm{kg}$ ) and placed on their left side. Polyvinyl catheters $(1.5 \mathrm{~mm}$ o.d.) were introduced into the maternal femoral artery and a branch of the uterine vein. The abdomen was incised in the midline, and the fetuses were exposed through an incision in the antimesenteric border of the uterus. Fetal blood samples were obtained from a branch of the umbilical artery. The sheep were given a spinal anesthetic ( 3 to $4 \mathrm{ml} 1 \%$ lidocaine hydrochloride) supplemented with barbiturate anesthesia. A right flank incision exposed the uterine horn, which was marsupialized to the edges of the abdominal incision. Branches of the umbilical artery and vein were exposed by a myometrial incision down to, but not into, the amniotic cavity, and polyvinyl catheters were passed through these branches into the main umbilical artery and vein (15).

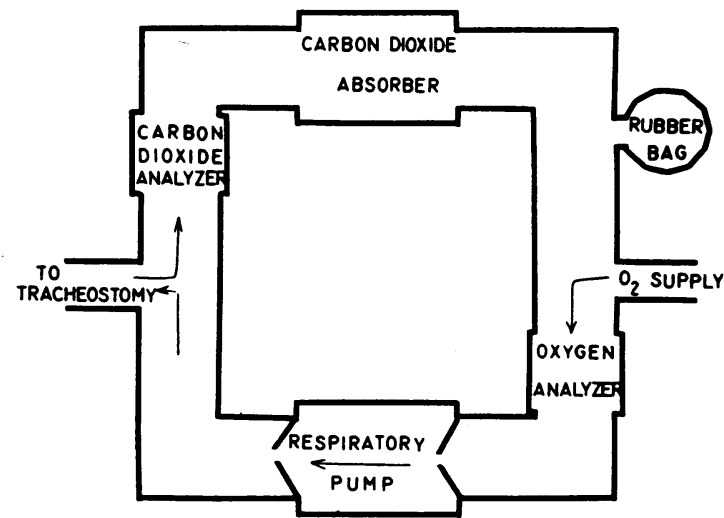

Fig. 1. Closed circuit for Rebreathing LOW CONCENTRATIONS OF CARBON MONOXIDE. 
After a tracheostomy with placement of an endotracheal tube the animals were placed on a closed rebreathing circuit. This circuit (Figure 1) had a volume of approximately $8 \mathrm{~L}$ and consisted of a Harvard respiratory pump (model 607), barium hydroxide $\mathrm{CO}_{2}$ absorber (Baralyme), and an oxygen supply with a Scott pressure operated demand valve (model 6480). This circuit was demonstrated to be airtight under the actual working conditions. The oxygen concentration was monitored with a Beckman paramagnetic $\mathrm{O}_{2}$ analyzer (model 11 ). The rate and depth of respiration and the $\mathrm{Po}_{2}$ within the closed circuit were adjusted as the experiment progressed; we attempted to maintain the arterial $\mathrm{Po}_{2}$ at $100 \mathrm{~mm} \mathrm{Hg}$. The arterial $\mathrm{PCO}_{2}$ was usually less than $40 \mathrm{~mm} \mathrm{Hg}$. Blood samples were collected in heparinized, silicone-greased, glass syringes, capped with mercury, labeled, placed in an ice bucket, and analyzed as rapidly as possible.

\section{Analytical procedures}

The following determinations were performed on the blood samples. $\mathrm{O}_{2}$ and $\mathrm{CO}_{2}$ contents were measured by the method of Van Slyke and Neill (error SD $\pm 4 \%$ ) (16). It was necessary to double the ferricyanide and acetic acid concentrations and to extract for 5 rather than 3 minutes owing to the slow release of $\mathrm{CO} . \mathrm{Po}_{2}$ was measured with a platinum electrode with a Mylar membrane (error $\pm 4 \%$ ). $\mathrm{PCO}_{2}$ was measured with an electrode with a Teflon membrane (error $\pm 3 \%$ ). $\mathrm{pH}$ was measured with an Instrumentation Laboratories glass electrode (model 107-1) (error $\pm 0.01 \mathrm{U}$ ). Hemoglobin was determined by the cyanmethemoglobin method (error \pm 0.12 per $100 \mathrm{ml}$ ) (17). Carbon monoxide content was measured with the infrared absorption method (18), with an error of \pm 0.006 $\mathrm{ml} \mathrm{CO}$ per $100 \mathrm{ml}$, or approximately $0.03 \%$ saturation, in the range of $\mathrm{CO}$ concentrations used in these experiments. Since methane and other heteroatomic gases to which the infrared meter might be sensitive are normally present in the rumen of the sheep, we tested for their possible interference with carboxyhemoglobin determinations by comparing sheep blood equilibrated with rumen gas and room air. We found no significant difference in carboxyhemoglobin concentration and concluded that the analytical method is insensitive to these other gases. Coburn, Danielson, Blakemore, and Forster (18) have reported this infrared analyzer to be 125 times as sensitive to $\mathrm{CO}$ as to methane. The oxyhemoglobin concentration $\left[\mathrm{O}_{2} \mathrm{Hb}\right]$ was determined by two independent techniques. 1) With the $\mathrm{Po}_{2}$ measurements, the $\left[\mathrm{O}_{2} \mathrm{Hb}\right]$ was read from appropriate

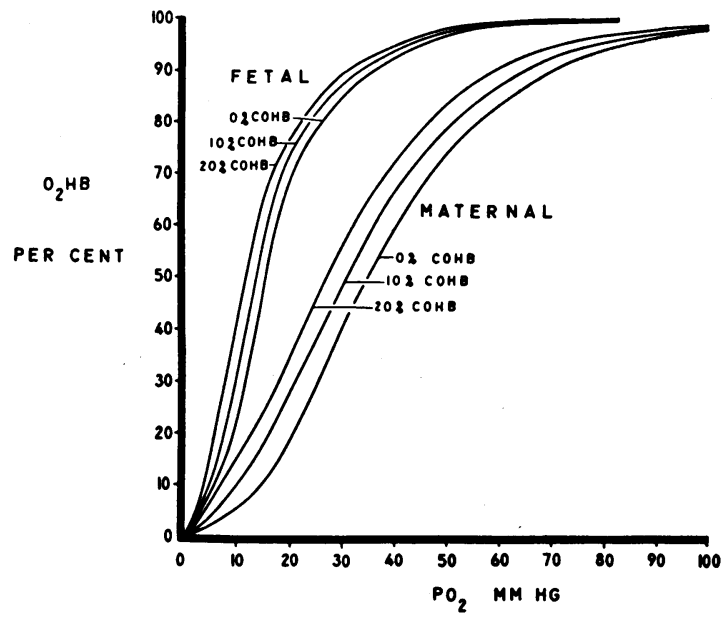

Fig. 2. SHEeP FETAL aNd MATERNAL OXYhEMOGLOBIN DISSOCIATION CURVES, SHOWING CARBON MONOXIDE EFFECT. The oxyhemoglobin curves are those reported by Meschia and co-workers $(20)$ at $\mathrm{pH} 7.4$ and $38^{\circ} \mathrm{C}$ with the curves of the ewe being an average value of the two types of adult hemoglobin. The effect of varying concentrations of carboxyhemoglobin $[\mathrm{COHb}]$ is calculated by the method of Roughton and Darling (23), and the $\left[\mathrm{O}_{2} \mathrm{Hb}\right]$ is that percentage of hemoglobin not bound as $\mathrm{COHb}$.

dissociation curves constructed for dogs (19) and an average of the curves for the two types of sheep hemoglobin (20). 2) The $\left[\mathrm{O}_{2} \mathrm{Hb}\right]$ was also determined as the quotient of the $\mathrm{O}_{2}$ content from the Van Slyke determination and the $\mathrm{O}_{2}$ capacity (hemoglobin concentration $[\mathrm{Hb}] \times 1.34$ ), a procedure that we believe is more accurate because of the variability of sheep dissociation curves. The animals' temperature was recorded periodically during the procedure and found to decrease 2 to $3^{\circ} \mathrm{C}$ as the experiment progressed. Corrections were made for the effects of $\mathrm{pH}$ and temperature (21). The presence of $\mathrm{COHb}$ also influences the $\left[\mathrm{O}_{2} \mathrm{Hb}\right]$ curve (22). This effect is illustrated for fetal and maternal sheep blood in Figure 2, by the method of Roughton and Darling (23).

\section{Calculations}

Placental diffusing capacity for CO (DPco) was calculated from the formula,
$\mathrm{DP}_{\mathrm{Co}}[$ milliliters per (minute $\times$ millimeters $\mathrm{Hg} \times$ kilograms fetal weight)

\begin{abstract}
in which $\dot{V}$ co is the rate of CO transfer across the placenta, $\overline{\mathrm{P}}_{\mathrm{M}}$ is the mean $\mathrm{CO}$ partial pressure in maternal placental blood, and PCOF is the mean $\mathrm{CO}$ partial pressure in fetal placental blood.

The rate of $\mathrm{CO}$ transfer across the placenta was determined by the formula,
\end{abstract}

$=\frac{\dot{\text { Vco }(m i l l i l i t e r s ~ p e r ~ m i n u t e) ~}}{\text { Pco } \mathbf{M}-\text { Pco } \text { (millimeters } \mathrm{Hg}) \times \text { kilograms fetal weight }}$

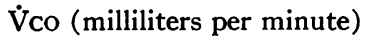

$$
\begin{aligned}
& =\frac{\Delta[\mathrm{COHb}]_{\mathrm{F}} \times \text { capacity } \times \mathrm{CO} \text { "space" } \mathrm{F}}{100 \times \text { minutes }},
\end{aligned}
$$

where $\Delta[\mathrm{COHb}]_{F}$ is the change in fetal $[\mathrm{COHb}]$ during the period of time under consideration, and capacity in 
milliliters per milliliter is calculated as $[\mathrm{Hb}] \times 1.34$. The CO "space" $F$ is defined as the change in total $C O$ in the fetus divided by the change in $\mathrm{CO}$ content in milliliters per milliliter of blood. For determination of fetal $\mathrm{CO}$ "space," approximately $5 \mathrm{ml}$ of blood containing $100 \%$ $\mathrm{COHb}$ was injected into the fetal circulation and the change in $[\mathrm{COHb}]_{\mathrm{F}}$ noted over a period of 15 to $30 \mathrm{~min}$ utes. The fetal CO "space" was usually $15 \%$ of body weight, but the range was from 10 to $15 \%$ and this can be expected to account for variation in the calculation of DP.

Pco was calculated with the Haldane relation (24),

Pco (millimeters $\mathrm{Hg}$ )

$$
=\frac{[\mathrm{COHb}] \times \mathrm{Po}_{2}(\text { millimeters } \mathrm{Hg})}{\mathrm{M} \times\left[\mathrm{O}_{2} \mathrm{Hb}\right]},
$$

which Paul and Roughton (25) have shown to be valid in the presence of reduced hemoglobin, as was encountered in some of these studies. $M$ is the relative affinity of hemoglobin for $\mathrm{CO}$ as compared with $\mathrm{O}_{2}$, usually given as 210 to 250 (26). The value of $M$ has been reported to vary with $\mathrm{pH}$ (27) and may also be different in maternal and fetal blood at the same $\mathrm{pH}$. We have determined $\mathrm{M}$ for maternal and fetal sheep blood obtaining 218 and 216, respectively, at $\mathrm{pH} 9.1,19^{\circ} \mathrm{C}$, using the method of Roughton (26).

The uterine venous Pco was chosen to represent the $\overline{\mathrm{P}} \mathrm{CO}_{\mathrm{M}}$, and umbilical venous Pco was selected as the $\overline{\mathrm{P}} \mathrm{CO}$. The justification for this is discussed below. The average maternal to fetal gradient, $\overline{\mathrm{P}} \mathrm{CO}_{\mathbf{M}}-\overline{\mathrm{P}} \mathrm{CO}_{\mathbf{F}}$, was then determined graphically from plots of these mean values during the time period from 10 to 60 minutes after the introduction of $\mathrm{CO}$ when the maternal-fetal Pco gradients were relatively large.

\section{Experimental procedures}

Three types of studies were performed.

A) Endogenous CO production. In these two studies, the arterial blood of a pregnant ewe placed on the rebreathing circuit with the abdominal cavity unopened was sampled over a 2- and 6-hour period. CO production was determined by measurement of the increase in $\mathrm{CO}$ content (milliliters per milliliter blood) during the period of observation.

B) Maternal to fetal CO transfer. In these experiments on six sheep and five dogs an initial period of 30 to 60 minutes was allowed during which the gas tensions in the closed circuit and in the maternal and fetal organisms approached a steady state. After this, $\mathrm{CO}$ was introduced into the closed circuit ( 15 to $50 \mathrm{ml}$ for dogs, and 25 to 100 $\mathrm{ml}$ for sheep), and serial blood samples were collected from the maternal and fetal vessels. Since $5 \mathrm{ml}$ of blood was required for the determinations on each sample, a single dog fetus was used for only one blood sample, and subsequent samples were taken from the other fetuses. In the fetal lambs serial samples were taken from the same fetus. The preparation was continued 3 to 9 hours, but measurements of DPco were made during the first hour of thestudy.

C) Fetal to maternal CO transfer. In an attempt to reach a steady state with elevated $\mathrm{COHb}$ levels in two sheep, we kept the unanesthetized, unrestrained animals for 15 to 18 hours in a sealed chamber of $3,000-\mathrm{L}$ capacity after they had inspired $175 \mathrm{ml}$ of $\mathrm{CO}$. At the end of this equilibration period, the ewes were removed from the chamber, anesthetized, and placed on the closed rebreathing circuit for 1 to 2 hours, a time provided to restore steady state conditions. The $[\mathrm{COHb}]_{\mathbf{M}}$ was then lowered as rapidly as possible by breathing the ewe with $100 \% \mathrm{O}_{2}$ on an open circuit for 1 to 2 hours until the $[\mathrm{COHb}]_{\mathrm{m}}$ had fallen to $1 \%$ or less. During this time the fetal and maternal gases were sampled and measured in a manner similar to that previously described.

\section{Results}

Endogenous CO production. In sheep no. 4 and 5 , the $\mathrm{CO}$ production of ewe and fetus combined averaged $0.4 \mathrm{ml} \mathrm{CO}$ per hour $\left(6.6 \times 10^{-3}\right.$ $\mathrm{ml} \mathrm{CO}$ per hour $\times \mathrm{kg}$ weight) (Figure 3), approximating the value in man of $0.4 \mathrm{ml}$ per hour (28).

Maternal to fetal $\mathrm{CO}$ transfer. The $\mathrm{O}_{2}$ and $\mathrm{CO}$ contents and tensions during the control period are shown in Table II. The average uterine and umbilical arteriovenous differences for $\mathrm{O}_{2}$ were $4.3 \mathrm{ml}$ per $100 \mathrm{ml}$ and $3.1 \mathrm{ml}$ per $100 \mathrm{ml}$, respectively, and these values are similar to those reported by others (1-4). Therefore we believe that our experimental preparation also is in a similar physiological state. Before the introduction of $\mathrm{CO}$ in the ewes, arterial $[\mathrm{COHb}]_{M}$ averaged $0.86 \%$. The fetal umbilical arterial $[\mathrm{COHb}]_{\mathrm{F}}$ averaged $2.9 \%$, with an average ratio of sheep $[\mathrm{COHb}]_{F} /[\mathrm{COHb}]_{M}$ of 3.2 . In the dogs the control $[\mathrm{COHb}]_{M}$ was $1.9 \%$, a value more than twice that found in nonpregnant dogs (29); the fetal value averaged $4.8 \%$ making the ratio $[\mathrm{COHb}]_{F} /[\mathrm{COHb}]_{M}$ 2.4. During this control period in both species the $[\mathrm{COHb}]$ rose

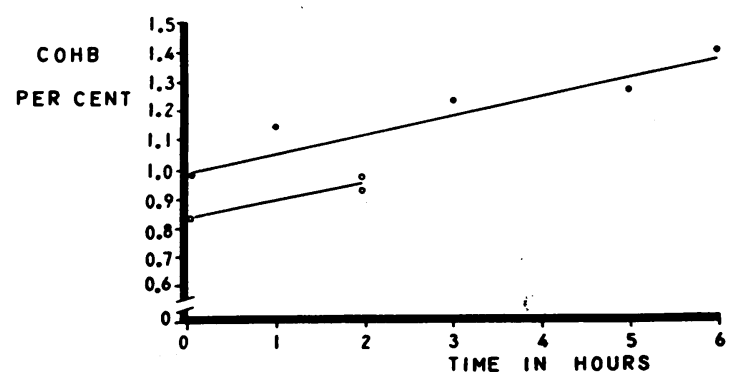

FIG. 3. ENDOGENOUS CARBON MONOXIDE PRODUCTION. Closed circles represent measurements from sheep 4, and the open circles represent measurements from sheep 5 . The $\mathrm{CO}$ production of the ewe and fetus combined averaged $0.4 \mathrm{ml}$ per hour. 
TABLE II

Control values of blood gases

\begin{tabular}{|c|c|c|c|c|c|c|c|c|c|c|c|c|c|}
\hline \multirow{2}{*}{\multicolumn{2}{|c|}{ Animal }} & \multicolumn{4}{|c|}{ Oxyhemoglobin concentration } & \multicolumn{4}{|c|}{ Po: } & \multicolumn{4}{|c|}{$\mathrm{pH}$} \\
\hline & & $\begin{array}{l}\text { Mat. } \\
\text { art. }\end{array}$ & $\begin{array}{c}\text { Ut. } \\
\text { vein }\end{array}$ & $\begin{array}{l}\text { Umb. } \\
\text { art. }\end{array}$ & $\begin{array}{l}\text { Umb. } \\
\text { vein }\end{array}$ & $\begin{array}{l}\text { Mat. } \\
\text { art. }\end{array}$ & $\begin{array}{c}\text { Ut. } \\
\text { vein }\end{array}$ & $\begin{array}{l}\text { Umb. } \\
\text { art. }\end{array}$ & $\begin{array}{l}\text { Umb. } \\
\text { vein }\end{array}$ & $\begin{array}{l}\text { Mat. } \\
\text { art. }\end{array}$ & $\begin{array}{c}\text { Ut. } \\
\text { vein }\end{array}$ & $\begin{array}{l}\text { Umb. } \\
\text { art. }\end{array}$ & $\begin{array}{l}\text { Umb } \\
\text { vein }\end{array}$ \\
\hline & & \multicolumn{4}{|c|}{$\%$} & \multicolumn{4}{|c|}{$m m \mathrm{Hg}$} & & & & \\
\hline Dog & $\begin{array}{r}7 \\
9 \\
10 \\
11 \\
12\end{array}$ & $\begin{array}{l}98 \\
98 \\
96.5 \\
96 \\
97\end{array}$ & $\begin{array}{l}49.5 \\
92 \\
74 \\
68 \\
76\end{array}$ & $\begin{array}{r}22 \\
24 \\
30 \\
14 \\
8\end{array}$ & & $\begin{array}{r}102 \\
173 \\
92 \\
88 \\
110\end{array}$ & $\begin{array}{l}31 \\
84 \\
41 \\
42 \\
43\end{array}$ & $\begin{array}{r}14 \\
15 \\
18 \\
11 \\
9\end{array}$ & & $\begin{array}{l}7.48 \\
7.46 \\
7.55 \\
7.39 \\
7.49\end{array}$ & $\begin{array}{l}7.36 \\
7.28 \\
7.43 \\
7.32 \\
7.43\end{array}$ & $\begin{array}{l}7.03 \\
7.1 \\
7.13 \\
7.13 \\
7.27\end{array}$ & \\
\hline Mean & & 97.1 & 71.8 & 20 & & 113 & 48 & 13 & & 7.47 & 7.36 & 7.13 & \\
\hline Sheep & $\begin{array}{l}1 \\
2 \\
3 \\
6 \\
7 \\
8\end{array}$ & $\begin{array}{l}97 \\
92 \\
97 \\
99 \\
95 \\
69\end{array}$ & $\begin{array}{l}70 \\
73 \\
83 \\
29 \\
42 \\
20\end{array}$ & $\begin{array}{l}60 \\
38.5 \\
28 \\
57 \\
42 \\
6\end{array}$ & $\begin{array}{l}62 \\
60 \\
44 \\
63 \\
58 \\
22\end{array}$ & $\begin{array}{r}98 \\
82 \\
89 \\
195 \\
96 \\
44\end{array}$ & $\begin{array}{l}39 \\
51 \\
55 \\
29 \\
34 \\
23\end{array}$ & $\begin{array}{r}19 \\
15 \\
13 \\
21 \\
15 \\
7\end{array}$ & $\begin{array}{l}23 \\
18 \\
19 \\
23 \\
21 \\
14\end{array}$ & $\begin{array}{l}7.62 \\
7.44 \\
7.55 \\
7.46 \\
7.36 \\
7.55\end{array}$ & $\begin{array}{l}7.55 \\
7.40 \\
7.52 \\
7.35 \\
7.25 \\
7.35\end{array}$ & $\begin{array}{l}7.37 \\
7.27 \\
7.22 \\
7.23 \\
7.12\end{array}$ & $\begin{array}{l}7.3 \\
7.39 \\
7.29 \\
7.18 \\
7.21\end{array}$ \\
\hline Mean & & 91.5 & 53 & 38.6 & 51.6 & 101 & 38.5 & 15 & 19.7 & 7.50 & 7.40 & 7.24 & 7.27 \\
\hline
\end{tabular}

${ }^{*} \mathrm{PO}_{2}=$ partial pressure of oxygen; Pco = partial pressure of carbon monoxide; mat. art. = maternal artery; ut. vein $=$ uterine vein; umb. art. $=$ fetal umbilical artery; umb. vein $=$ fetal umbilical vein; $[\mathrm{COHb}]_{\mathrm{F}} /[\mathrm{COHb}]_{\mathrm{M}}=\mathrm{ratio}$ of fetal carboxyhemoglobin to maternal carboxyhemoglobin; $\overline{\mathrm{P}} \mathrm{CO}_{\mathrm{F}}-\overline{\mathrm{P}} \mathrm{CO}_{\mathrm{M}}=$ partial pressure gradient of $\mathrm{CO}$ between mother and fetus.

slightly as time passed, reflecting the endogenous production of $\mathrm{CO}$. In sheep the Pco averaged approximately $0.0030 \mathrm{~mm} \mathrm{Hg}$ on the maternal side of the placenta and $0.0054 \mathrm{~mm} \mathrm{Hg}$ on the fetal side, with a mean tension gradient of 0.0024 $\mathrm{mm} \mathrm{Hg}$. This gradient is greater than predicted because the Pco in the fetal and in the maternal capillary beds should have been in equilibrium, except for the relatively small gradient resulting from the endogenously produced $\mathrm{CO}$ in the fetus (a matter of $2 \times 10^{-4} \mathrm{~mm} \mathrm{Hg}$; see Discussion).

After the introduction of $\mathrm{CO}$, the $[\mathrm{COHb}]_{\mathrm{M}}$ rose rapidly (Figure 4), reaching a peak in 5 to 10 minutes, then rapidly declined to 80 to $85 \%$ of the initial peak within the next 5 to $10 \mathrm{~min}$ utes and continued to decrease slowly for several hours as $\mathrm{CO}$ crossed the placenta to the fetus. It would be predicted that eventually the $[\mathrm{COHb}]_{\mathrm{M}}$ should start to rise reflecting endogenous $\mathrm{CO}$ production; however, this was not noted in these studies, presumedly because our observations did not continue long enough.

The $[\mathrm{COHb}]_{\mathrm{F}}$ slowly rose for several hours as $\mathrm{CO}$ crossed the placenta (Figure 4); the rate of fetal $\mathrm{CO}$ uptake ( $\dot{V}_{\mathrm{CO}}$ ) averaged $0.034 \mathrm{ml}$ per minute in sheep and $0.0035 \mathrm{ml}$ per minute in dogs during the hour after the introduction of CO. Wise and Drabkin have recently shown that the hemophagous organ of the dog placenta produces $\mathrm{CO}$ as a consequence of hemoglobin metabolism (30), but the magnitude of this production is small. The measurement of $\dot{V}$ co will be slightly overestimated due to endogenous production of $\mathrm{CO}$ by the fetus and the placenta. This $\mathrm{CO}$ production is probably about $2 \times 10^{-2} \mathrm{ml}$ per hour for a fetus weighing $3 \mathrm{~kg}$, and when contrasted with the $\dot{\mathrm{V}} \mathrm{CO}$ of $2 \mathrm{ml}$ per hour during the

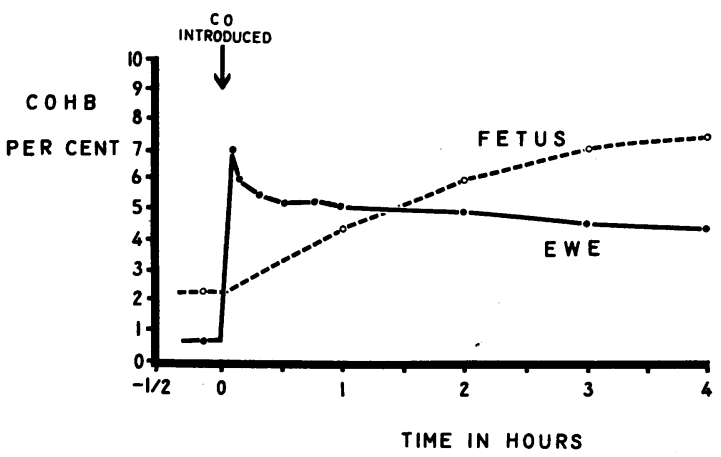

Fig. 4. PER CENT CARboxyhemoglobin OF MATERnal ARTERIAL BLOOD, AND OF THE AVERAGE OF FETAL UMBILICAL ARTERIAL AND VENOUS BLOOD DURING MATERNAL TO FETAL CO EXCHANGE IN SHEEP 7. The fetal uptake of CO, $\dot{\mathrm{V}} \mathrm{CO}$, is the product of the change in $[\mathrm{COHb}]$ in the fetus $\left([\mathrm{COHb}]_{\mathrm{F}}\right)$ from 10 to 60 minutes, the $\mathrm{CO}$ capacity of fetal blood, and the fetal CO "space." 
TABLE II

and $p H$ in dogs and sheep*

\begin{tabular}{|c|c|c|c|c|c|c|c|c|c|}
\hline \multicolumn{5}{|c|}{ Carboxyhemoglobin concentration } & \multicolumn{5}{|c|}{ Pco } \\
\hline $\begin{array}{l}\text { Mat. } \\
\text { art. }\end{array}$ & $\begin{array}{l}\text { Ut. } \\
\text { vein }\end{array}$ & $\begin{array}{l}\text { Umb. } \\
\text { art. }\end{array}$ & $\begin{array}{l}\text { Umb. } \\
\text { vein }\end{array}$ & $\begin{array}{c}{[\mathrm{COHb}]_{\mathrm{F}} /} \\
{[\mathrm{COHb}]_{\mathrm{M}}}\end{array}$ & $\begin{array}{l}\text { Mat. } \\
\text { art. }\end{array}$ & $\begin{array}{l}\text { Ut. } \\
\text { vein }\end{array}$ & $\begin{array}{c}\text { Umb. } \\
\text { art. }\end{array}$ & $\begin{array}{c}\text { Umb. } \\
\text { vein }\end{array}$ & $\frac{\overline{\mathrm{P}}_{\text {COF }}-}{\overline{\mathrm{P}}_{\text {COM }}}$ \\
\hline \multicolumn{5}{|c|}{$\%$} & \multicolumn{5}{|c|}{$m m \mathrm{Hg}$} \\
\hline 2.39 & 2.34 & 6.14 & & 2.6 & 0.0096 & 0.0051 & 0.0156 & & 0.0083 \\
\hline 1.73 & 1.94 & $4.5 \overline{7}$ & & 2.49 & 0.0122 & 0.0071 & 0.014 & & 0.0069 \\
\hline 1.75 & 2.1 & 3.6 & & 1.87 & 0.0066 & 0.0046 & 0.0086 & & 0.0030 \\
\hline 1.3 & 1.68 & 3.85 & & 2.58 & 0.0048 & 0.0042 & 0.0121 & & 0.0076 \\
\hline 2.28 & 2.2 & 5.92 & & 2.64 & 0.0104 & 0.005 & 0.0223 & & 0.015 \\
\hline 1.9 & 2.0 & 4.8 & & 2.44 & 0.0087 & 0.0052 & 0.0145 & & 0.0082 \\
\hline 1.2 & 1.54 & 3.97 & 3.82 & 2.85 & 0.0048 & 0.0034 & 0.0050 & 0.0057 & 0.0016 \\
\hline 1.12 & 1.1 & 3.7 & 3.6 & 3.32 & 0.004 & 0.0031 & 0.0058 & 0.0043 & 0.0017 \\
\hline 1.0 & 1.05 & 3.8 & 3.5 & 3.65 & 0.0037 & 0.0028 & 0.0070 & 0.0060 & 0.0035 \\
\hline 0.55 & 0.67 & 1.76 & 1.92 & 3.0 & 0.0043 & 0.0027 & 0.0026 & 0.0028 & 0.0002 \\
\hline 0.63 & 0.63 & 2.3 & & 3.64 & 0.0025 & 0.0020 & 0.0033 & 0.0033 & 0.0012 \\
\hline 0.66 & 0.79 & 1.9 & 1.9 & 2.6 & 0.0017 & 0.0036 & 0.0089 & 0.0097 & 0.0062 \\
\hline 0.86 & 0.95 & 2.9 & 2.95 & 3.2 & 0.0031 & 0.0029 & 0.0054 & 0.0053 & 0.0024 \\
\hline
\end{tabular}

period of $\mathrm{CO}$ exchange will result in an error of about $1 \%$.

The $\bar{P} \mathrm{CO}_{M}$ followed a course similar to that of the $[\mathrm{COHb}]_{\mathrm{M}}$ after $\mathrm{CO}$ was introduced (Figure 5). The fetal $\overline{\mathrm{P}} \mathrm{CO}_{\mathrm{F}}$ rose slowly as $\mathrm{CO}$ crossed the placenta. In the sheep, the mean tension gradient, $\overline{\mathrm{P}}_{\mathrm{CO}_{\mathrm{M}}}-\overline{\mathrm{P}} \mathrm{CO}_{\mathrm{F}}$, during the 50 or 60 minutes

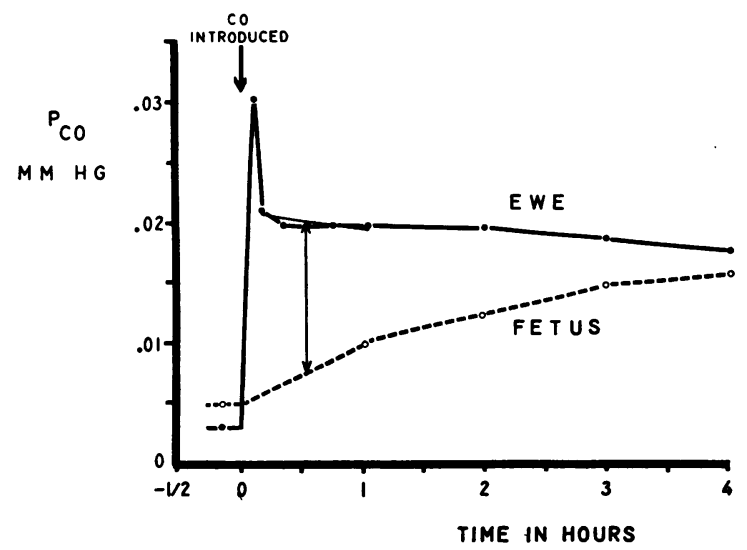

Fig. 5. Maternal AND fetal Mean Partial PresSURES OF CO ( $\overline{\mathrm{P}} \mathrm{CO}_{\mathbf{M}}, \overline{\mathrm{P}} \mathrm{CO}$ ) DURING MATERNAL TO FETAL CO EXChange IN SHEEP 7 . The mean gradient ( $\overline{\mathrm{P}} \mathrm{CO}_{\mathbf{m}}-$ $\overline{\mathrm{P}}_{\mathrm{CO}}$ ) during the period from 10 to 60 minutes after giving $\mathrm{CO}$ is shown by the arrow. Seven hours after the administration of $\mathrm{CO}$ the $\overline{\mathrm{P}} \mathrm{CO}$ had not equilibrated with the $\overline{\mathrm{P}} \mathrm{CO}$. when $\mathrm{CO}$ exchange was studied averaged 0.022 $\mathrm{mm} \mathrm{Hg}$, and in the dogs, in which relatively larger amounts of $\mathrm{CO}$ were used, the gradient averaged $0.034 \mathrm{~mm} \mathrm{Hg}$. Approximately 7 hours after introduction of $\mathrm{CO}$ the $\overline{\mathrm{P}} \mathrm{CO}_{\mathrm{M}}$ was $0.019 \mathrm{~mm}$ $\mathrm{Hg}$, the $\overline{\mathrm{P}}_{\mathrm{CO}}$ was 0.018 , and equilibration had not been reached.

The rate of $\mathrm{CO}$ transfer $(\dot{\mathrm{V}} \mathrm{CO})$ was linear with the $\overline{\mathrm{P}}_{\mathrm{CO}_{M}}-\overline{\mathrm{P}}_{\mathrm{CO}}$ (Figure 6), a finding indicating that $\mathrm{CO}$ exchange is limited by diffusion rather than by placental blood flow, and that these experimental animals were in a similar physiologic state.

The $\mathrm{DP}_{\mathrm{Co}}$ in sheep ranged from 0.61 to $1.98 \mathrm{ml}$ per (minute $\times \mathrm{mm} \mathrm{Hg}$ ) and averaged $1.51 \mathrm{ml}$ per (minute $\times \mathrm{mm} \mathrm{Hg}$ ) (Table III). In the dogs the range was from 0.072 to 0.155 and averaged $0.11 \mathrm{ml}$ per (minute $\times \mathrm{mm} \mathrm{Hg}$ ). In view of the marked variation in the size of the fetuses, a perhaps more meaningful expression of $\mathrm{DP}_{\mathrm{CO}}$ is in relation to fetal weight. In these terms the sheep $\mathrm{DP}_{\mathrm{CO}}$ ranged from 0.31 to $0.64 \mathrm{ml}$ per (minute $\times \mathrm{mm} \mathrm{Hg} \times \mathrm{kg}$ fetal weight), averaging $0.54 \mathrm{ml}$ per (minute $\times \mathrm{mm} \mathrm{Hg} \times \mathrm{kg}$ ) (SD $\pm 0.13)$. The corresponding values for dogs were 0.39 to $0.77 \mathrm{ml}$ per (minute $\times \mathrm{mm} \mathrm{Hg}$ $\times \mathrm{kg}$ ), and $0.57 \mathrm{ml}$ per (minute $\times \mathrm{mm} \mathrm{Hg} \times \mathrm{kg}$ ) $(\mathrm{SD} \pm 0.18)$, respectively. 
TABLE III

Placental diffusing capacity for $C O(D \mathrm{P} c o)$ during maternal to fetal $C O$ exchange*

\begin{tabular}{|c|c|c|c|c|c|c|c|c|c|c|c|c|c|}
\hline \multicolumn{2}{|c|}{ Animal } & $\begin{array}{c}\text { CO } \\
\text { given }\end{array}$ & $\begin{array}{c}\text { Mean } \\
\text { COHbM }\end{array}$ & $\begin{array}{l}\text { CO capac- } \\
\text { ity of } \\
\text { fetal } \\
\text { blood }\end{array}$ & $\begin{array}{c}\text { Fetal } \\
\text { CO } \\
\text { "space" }\end{array}$ & $\triangle \mathrm{COHbF}$ & $\begin{array}{c}\text { CO } \\
\text { trans- } \\
\text { ferred }\end{array}$ & VcoF & $\overline{\text { Рсом }}$ & $\overline{\text { Pcor }}$ & $\begin{array}{l}\text { PсOM- } \\
\text { Pcor }\end{array}$ & DPCO & DPco \\
\hline & & $m l$ & $\%$ & $m l / m l$ & $m l$ & $\%$ & $m l$ & $\mathrm{ml} / \mathrm{min}$ & $m m \mathrm{Hg}$ & $m m \mathrm{Hg}$ & $m m \mathbf{H g}$. & $\underset{m m H g}{m l / \min \times}$ & $\underset{\times \underset{\times k g}{m l / m i n}}{\times{ }^{m m} H g}$ \\
\hline \multirow[t]{5}{*}{ Dog } & 7 & 45.2 & 37 & 0.17 & 36 & 3.3 & 0.20 & 0.0045 & 0.079 & 0.031 & 0.048 & 0.093 & 0.39 \\
\hline & 9 & 27.2 & 28 & 0.19 & 28.5 & 7.3 & 0.39 & 0.0039 & 0.066 & 0.028 & 0.038 & 0.104 & 0.55 \\
\hline & 10 & 27.2 & 26 & 0.18 & 37.6 & 2.7 & 0.19 & 0.0046 & 0.061 & 0.018 & 0.043 & 0.108 & 0.43 \\
\hline & 11 & 31.6 & 13.5 & 0.15 & 35.0 & 2.2 & 0.12 & 0.0029 & 0.035 & 0.016 & 0.019 & 0.155 & 0.77 \\
\hline & 12 & 18.1 & 19 & 0.18 & 16.4 & 2.1 & 0.061 & 0.0015 & 0.042 & 0.022 & 0.021 & 0.072 & 0.72 \\
\hline \multicolumn{2}{|l|}{$\begin{array}{l}\text { Mean } \\
\text { SD }\end{array}$} & 29.9 & 24.8 & 0.17 & 30.1 & 3.7 & 0.15 & 0.0035 & 0.057 & 0.023 & 0.034 & $\begin{array}{c}0.11 \\
\pm 0.027\end{array}$ & $\begin{array}{r}0.57 \\
\pm 0.18\end{array}$ \\
\hline \multirow[t]{6}{*}{ Sheep } & 1 & 91 & 18 & 0.19 & 450 & 4.4 & 3.74 & 0.066 & 0.044 & 0.010 & 0.034 & 1.98 & 0.64 \\
\hline & 2 & 91 & 14 & 0.14 & 451 & 5.1 & 3.1 & 0.056 & 0.045 & 0.013 & 0.032 & 1.78 & 0.60 \\
\hline & 3 & 45.5 & 7.7 & 0.15 & 300 & 1.3 & 0.59 & 0.011 & 0.026 & 0.0086 & 0.017 & 0.61 & 0.31 \\
\hline & 6 & 31.6 & 4.7 & 0.16 & 580 & 2.2 & 2.0 & 0.029 & 0.020 & 0.005 & 0.015 & 1.92 & 0.50 \\
\hline & 7 & 31.6 & 5.3 & 0.15 & 339 & 2.2 & 1.12 & 0.019 & 0.021 & 0.0075 & 0.014 & 1.39 & 0.60 \\
\hline & 8 & 22.7 & 6.4 & 0.17 & 360 & 2.4 & 1.49 & 0.026 & 0.032 & 0.014 & 0.019 & 1.37 & 0.57 \\
\hline $\begin{array}{l}\text { Mean } \\
\text { SD }\end{array}$ & & 52.2 & 9.4 & 0.16 & 413 & 2.9 & 2.0 & 0.034 & 0.031 & 0.0097 & 0.022 & $\begin{array}{r}1.51 \\
\pm 0.51\end{array}$ & $\begin{array}{r}0.54 \\
\pm 0.13\end{array}$ \\
\hline
\end{tabular}

* Abbreviations in addition to those in Table II $:$ VCOF $=$ fetal uptake of $\mathrm{CO} ; \overline{\mathrm{PCO}}=$ mean maternal partial pressure of $\mathrm{CO} ; \overline{\mathrm{PCOF}}=$ mean fetal partial pressure of $\mathrm{CO}$.

Fetal to maternal CO transfer. In the two sheep studied after 15 to 18 hours in a closed chamber the ratios of $[\mathrm{COHb}]_{F} /[\mathrm{COHb}]_{M}$ were 2.13 and 2.41. When the ewe was ventilated

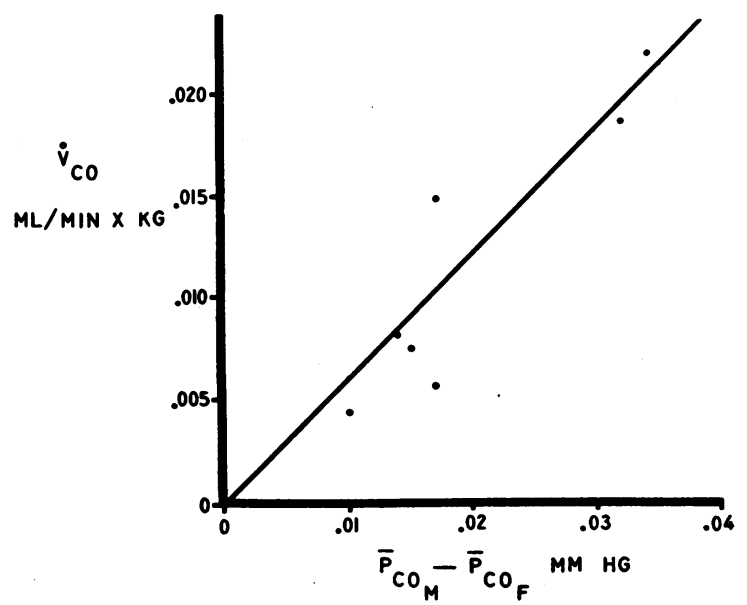

Fig. 6. UPTAKE OF CO ( $\dot{V} C O)$ IN SHEEP DURING MATERNAL TO FETAL AND FETAL TO MATERNAL CO EXCHANGE AS A FUNCTION OF THE MEAN MATERNAL-FETAL PARTIAL PRESSURE GRADIENT FOR CO $\left(\mathrm{PCO}_{\mathrm{M}}-\mathrm{PCO}_{\mathrm{F}}\right)$. The least mean squares regression line, $y=0.59 x$, with the restriction that it must pass through the origin, is shown. The linear relation suggests that the exchange of $\mathrm{CO}$ is limited by diffusion rather than blood flow in the maternal and fetal placental capillaries. with oxygen, the $[\mathrm{COHb}]_{\mathrm{M}}$ fell to less than $1 \%$ within 30 minutes (Figure 7 ). The $[\mathrm{COHb}]_{F}$ fell at a relatively constant rate while the ewe breathed $\mathrm{O}_{2}$. The fetal and maternal $\overline{\mathrm{P}} \mathrm{Co}$ followed a course similar to that of the $[\mathrm{COHb}]$ (Figure 8).

.In these sheep the diffusing capacities (Table IV) were 1.29 and $1.53 \mathrm{ml}$ per (minute $X \mathrm{~mm}$ $\mathrm{Hg}$ ) or 0.34 and $0.75 \mathrm{ml}$ per (minute $\times \mathrm{mm} \mathrm{Hg}$ $X \mathrm{~kg}$ fetal weight). These values are similar to those obtained when $\mathrm{CO}$ moved from mother to fetus.

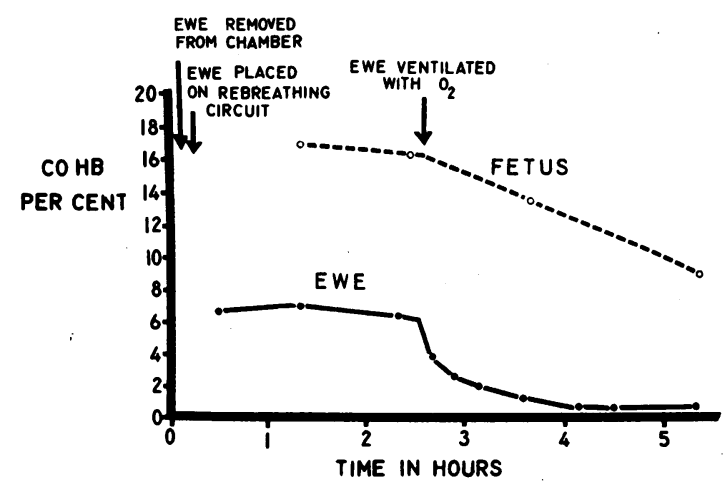

Fig. 7. Maternal AND fetal PER CENT CarboxyHEMOGLOBIN DURING FETAL TO MATERNAL EXCHANGE IN SHEEP 11. 


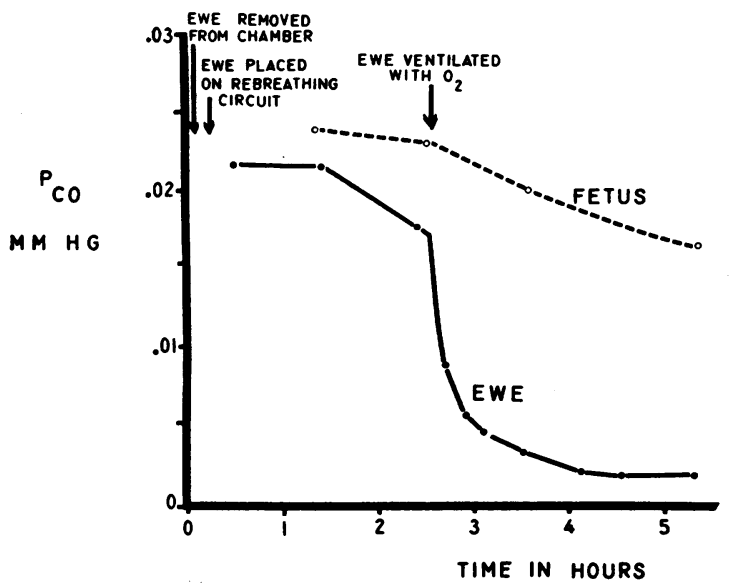

Fig. 8. Maternal aNd fetal CO partial pressure $\left(\bar{P}_{\mathrm{CO}_{M}}, \overline{\mathrm{P}}_{\mathrm{F}}\right.$ ) DURING FETAL TO MATERNAL CO EXCHANGE IN SHEEP 11.

\section{Discussion}

Placental diffusing capacity for CO during maternal to fetal $\mathrm{CO}$ transfer. After the introduction of $\mathrm{CO}$ into the rebreathing circuit the gas rapidly entered the blood of both sheep and dogs and reached a peak concentration. Then it was distributed in relatively rapidly exchanging extravascular compartments causing the $[\mathrm{COHb}]_{\mathrm{M}}$ to fall for 30 to 60 minutes. Most of this rapidly equilibrating extravascular pool is probably myoglobin (of red muscle), which binds approximately $5 \%$ of the total body $\mathrm{CO}$ at equilibrium (31). More slowly equilibrating pools of $\mathrm{CO}$, containing stored erythrocytes, are the spleen, bone marrow, skin, and perhaps even Barkans pseudohemoglobin and bile pigments, and in the pregnant animal, the fetus.

The $[\mathrm{COHb}]_{F}$ rose slowly, reaching the $[\mathrm{COHb}]_{M}$ in 1 to 2 hours (Figure 4), and approached a steady state only after 7 hours at which time the $[\mathrm{COHb}]_{\mathrm{M}}$ was $4.1 \%$ and the $[\mathrm{COHb}]_{\mathrm{F}}$ was $8.4 \%$. The total quantity of $\mathrm{CO}$ taken up by the fetus was quite variable, depending upon its size, the $[\mathrm{COHb}]_{M}$, and the duration of the study, and was less than that lost by the mother. Thus, in one experiment (sheep 3) approximately $10.7 \mathrm{ml}$ of $\mathrm{CO}$ left the maternal blood from 60 minutes, by which time the rapidly exchanging $\mathrm{CO}$ pools should have approached equilibrium, to the end of the experiment approximately 8 hours later. In contrast, approximately $1.13 \mathrm{ml}$ of $\mathrm{CO}$ was taken up by the first fetus and $3.25 \mathrm{ml}$ by its twin for a total of $4.4 \mathrm{ml} \mathrm{CO}$, or less than half of that given up by the ewe. As the experiment progressed, however, the rate of maternal loss approached the rate of fetal gain. In other experiments a similar pattern was seen.

During the course of an experiment CO may have continued to enter slowly equilibrating pools other than the fetus such as the amniotic and allantoic fluid, the volume of which in these pregnant ewes was about $1,000 \mathrm{ml}$ (range $=500$ to $1,500 \mathrm{ml}$ ). The measured $\mathrm{CO}$ content of this fluid, when $[\mathrm{COHb}]_{\mathrm{M}}$ was $7 \%$ and the $[\mathrm{COHb}]_{\mathrm{F}}$ was $17 \%$ (sheep 11), was 0.0000037 (or $3.7 \times 10^{-6}$ ) ml CO per ml amniotic fluid, or a total of about $0.0037 \mathrm{ml}$. The Bunsen solubility coefficient $(\alpha)$ of $\mathrm{CO}$ in saline at $40^{\circ} \mathrm{C}$ is 0.0000234 (or $2.34 \times 10^{-5}$ ) $\mathrm{ml} \mathrm{CO}$ per $\mathrm{ml}$ per $\mathrm{mm} \mathrm{Hg}$ (32) so that at the Pco of maternal venous blood, $0.02 \mathrm{~mm} \mathrm{Hg}$, the expected $\mathrm{CO}$ content at equilibrium should have been approximately 0.00000047 (or $4.7 \times 10^{-7}$ ) $\mathrm{ml} \mathrm{CO}$ per $\mathrm{ml}$ of amniotic fluid. It is clear that the amount of $\mathrm{CO}$ dissolved in amniotic fluid cannot account for the discrepancy between the amount

TABLE IV

Placental diffusing capacity for $C O$ (DPco) during fetal to maternal CO exchange*

\begin{tabular}{|c|c|c|c|c|c|c|c|c|c|c|}
\hline Animal & $\underset{\text { given }}{\text { Co }}$ & $\begin{array}{c}\text { Mean } \\
\text { COHbM }\end{array}$ & $\begin{array}{c}\text { Mean } \\
\text { COHbr }\end{array}$ & $\begin{array}{c}\mathrm{CO} \\
\text { trans- } \\
\text { ferred }\end{array}$ & $\dot{\mathrm{V}} \mathrm{co}$ & $\overline{\mathbf{P}}$ COF & $\overline{\mathrm{P}}$ COM & $\begin{array}{l}\overline{\text { Pcor- }} \\
\overline{\text { Pcom }}\end{array}$ & DPCo & DPCo \\
\hline & $m l$ & $\%$ & $\%$ & $m l$ & $m l / m i n$ & $m m \mathrm{Hg}$ & $m m \mathrm{Hg}$ & $m m \mathrm{Hg}$ & $\underset{\times m m H g}{m l / m i n}$ & $\underset{\times \underset{\times k g}{m l / m i n}}{\operatorname{mm} H g}$ \\
\hline $\begin{array}{r}\text { Sheep } 9 \\
11\end{array}$ & $\begin{array}{l}270 \\
300\end{array}$ & $\begin{array}{l}3.12 \\
7.06\end{array}$ & $\begin{array}{r}6.77 \\
16.95\end{array}$ & $\begin{array}{l}0.77 \\
5.1\end{array}$ & $\begin{array}{l}0.013 \\
0.029\end{array}$ & $\begin{array}{l}0.015 \\
0.021\end{array}$ & $\begin{array}{l}0.005 \\
0.0038\end{array}$ & $\begin{array}{l}0.01 \\
0.017\end{array}$ & $\begin{array}{l}1.29 \\
1.53\end{array}$ & $\begin{array}{l}0.34 \\
0.75\end{array}$ \\
\hline Mean & & & & & & & & & 1.41 & 0.54 \\
\hline
\end{tabular}

* Additional abbreviation : $\dot{\mathrm{V}} \mathrm{co}=$ amount of $\mathrm{CO}$ given up by fetus. 


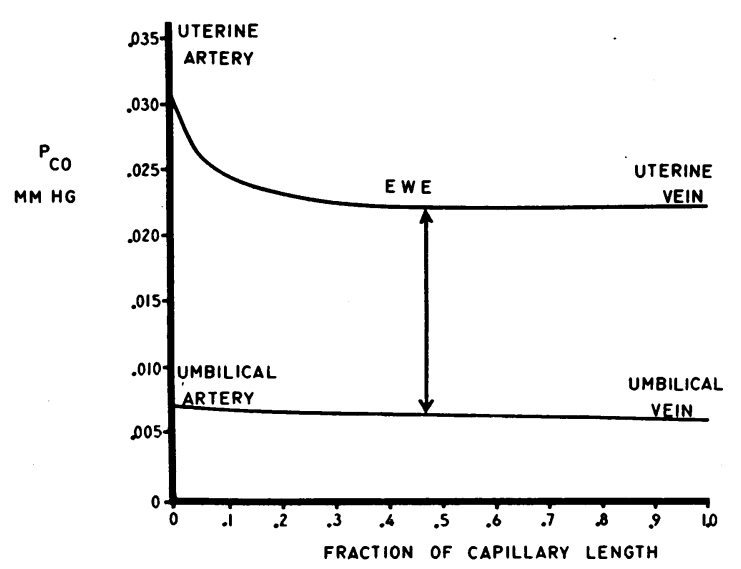

Fig. 9. Maternal and fetal partial pressure of CO (PCO) DURING THE COURSE OF A SINGLE CAPILLARY TRANSIT DURING MATERNAL TO FETAL CO EXCHANGE. Data are from sheep 7 , at mean $[\mathrm{COHb}]_{\mathrm{M}}=7.7 \%$, maternal $\mathrm{pH}=7.5,[\mathrm{COHb}]_{\mathbf{F}}=3.5 \%$, and fetal $\mathrm{pH}=$ 7.2. The change of $\mathrm{Po}_{2}$ along the capillary was calculated by the Lamport modification (49) of the Bohr integration assuming concurrent flow, and Pco values were calculated by the Haldane relationship (Equation 3). The mean maternal-fetal Pco gradient $\left(\overline{\mathrm{P}} \mathrm{CO}_{\mathrm{M}}-\overline{\mathrm{P}} \mathrm{CO}_{\mathrm{F}}\right)$ is indicated by the arrow, and it will be seen that $\overline{\mathrm{P}} \mathrm{CO}_{\mathrm{M}}$ and $\overline{\mathrm{P}} \mathrm{COF}$ approximate the value of $\mathrm{PCO}$ in the respective veins.

of $\mathrm{CO}$ given up by the ewe and that taken up by the fetus.

A theoretical calculation of the Pco in the maternal and fetal placental capillaries is plotted in Figure 9, using average data from the measurements in sheep 7. A number of simplifying assumptions have been made including an assumption that the capillaries are uniform, that their flow is concurrent (that is, maternal and fetal capillaries are parallel and the two bloodstreams flow in the same direction), and that blood samples from the uterine and umbilical veins are truly representative of the end capillary blood of the maternal and fetal placental circulations, respectively. This Figure has been presented to illustrate the following important points: 1) The calculated change in Pco along the capillary is not great enough to invalidate the use of a single value for the gradient. This is largely because the concentration of $\mathrm{COHb}$ does not alter very much during one capillary transit, and although the $\mathrm{Po}_{2}$ and $\left[\mathrm{O}_{2} \mathrm{Hb}\right]$ change considerably along the capillary, their ratio, which determines the equilibrated Pco (see Equation 3 ), does not change nearly as much. 2) The
Pco of the fetal placental capillary blood is much less than that of the maternal placental capillary blood and does not approach the latter even at the end of the capillary. 3) The Pco difference obtained by subtracting the values at the venous end of the respective capillaries is not substantially different from the correct mean difference.

Figure 10, a plot of change in maternalfetal Pco gradient during maternal-fetal $\mathrm{CO}$ exchange, shows that, after the first few minutes of mixing when there is a rapid disappearance of $\mathrm{CO}$, the change in gradient appears to follow a simple exponential process for a first-order reaction with a half-time of approximately 2 hours.

The sheep fetuses survived 2 to 8 hours after the introduction of $\mathrm{CO}$. In several cases the cause of death was anoxia secondary to maternal pulmonary edema. Acute blood loss was undoubtedly a factor in some fetal deaths, because 4 to $8 \mathrm{ml}$ of blood was drawn for each set of determinations and after 4 to 5 hours this could amount to a significant fraction of the fetal blood volume. However, the $\mathrm{CO}$ diffusing capacity was measured during the first hour of the study when less than $7 \%$ of the fetal blood volume had been removed and the fetus was in good condition. Although a high level of blood [COHb] may have been a factor in fetal death, in sheep 11 twin fetuses both survived a number of hours with blood [COHb] at $17 \%$. In the studies on dogs, each fetus was sacrificed after a single blood sample had been obtained because the minimal sample volume represented such a large proportion of the animal's blood volume.

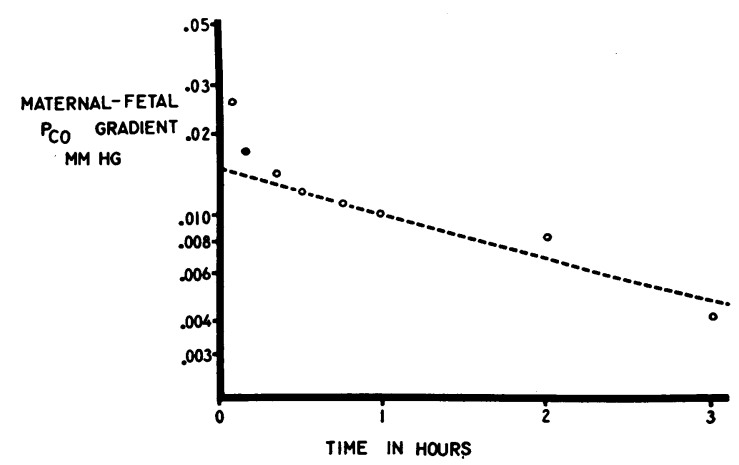

Fig. 10. Mean maternal-Fetal CO Partial presSURE GRADIENTS ( $\left.\overline{\mathrm{P}}_{\mathrm{M}}-\overline{\mathrm{P}} \mathrm{CO}_{\mathrm{F}}\right)$ DURING MATERNAL TO FETAL CO EXCHANGE IN SHEEP 7. 
The calculations of $\mathrm{CO}$ diffusing capacity ${ }^{1}$ are based on several assumptions, including the following: 1) $\mathrm{CO}$ is not metabolized or otherwise lost from the system during measurement. 2) The "CO space" of the mother and fetus is constant. 3) $\overline{\mathrm{P}} \mathrm{CO}_{\mathrm{M}}$ is approximately the same as the Pco in the uterine vein (see Figure 9), and $\overline{\mathrm{P}}_{\mathrm{CO}_{\mathrm{F}}}$ is approximately that of the umbilical venous Pco. 4) The dimensions and spatial relationships of the maternal and fetal capillary bed are constant during the measurement. In sheep 7 during the period of $\mathrm{CO}$ exchange calculation of $D_{P_{C O}}$ was $0.60,0.60$, and $0.62 \mathrm{ml}$ per (minute $\times \mathrm{mm} \mathrm{Hg} \times \mathrm{kg}$ ) over the time period 0 to 15 minutes, 45 to 60 minutes, and 120 to 180 minutes, respectively. This suggests that the last assumption is valid and that the animals' physiologic state was not deteriorating during measurement of diffusing capacity.

It is of interest that the $\mathrm{DP}_{\mathrm{CO}}$ of sheep, which have a five layered syndesmochorial (35) or six layered epitheliochorial placenta (36), was the same as the $\mathrm{DP}_{\mathrm{CO}}$ of dogs with a four layered endotheliochorial placenta (35).

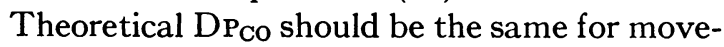
ment of $\mathrm{CO}$ from mother to fetus as from fetus to mother, and we find this to be the case (Table III and IV). This theoretical conclusion is obvious insofar as diffusion across the placental membrane is concerned, but is less apparent when the reactions of $\mathrm{CO}$ with intracellular hemoglobin are considered. It is essential to appreciate that theta, the rate of uptake of $\mathrm{CO}$ per milliliter of whole blood for a gradient of $1 \mathrm{~mm} \mathrm{Hg}$ of Pco between the plasma and the interior of the red cell, applies equally well to the movement of $\mathrm{CO}$ out of the red cell (see Appendix).

In terms of the mass of the organism, the diffusing capacity of the placenta is similar to that of the lung. For example, a $70-\mathrm{kg}$ man

\footnotetext{
1 The term "diffusing capacity" (DP) is perhaps confusing since what is measured is not necessarily the maximal exchange possible. Actually DP may be less a measure of the diffusion characteristics of the placental membrane than of the maternal and fetal capillary blood volumes and the chemical reaction rates of CO with hemoglobin (33). Other terms such as "diffusion constant" (1) and "diffusion coefficient" (34) have been used for placental gas exchange, but "diffusing capacity" is a term well entrenched in physiological literature and has previously been used in reference to the placenta ( 3 ).
}

with normal pulmonary diffusing capacity of 30 $\mathrm{ml}$ per (minute $\times \mathrm{mm} \mathrm{Hg}$ ) has a diffusing capacity of $0.43 \mathrm{ml}$ per (minute $\times \mathrm{mm} \mathrm{Hg} \times \mathrm{kg}$ ); our comparable values for the placental diffusing capacity average $0.54 \mathrm{ml}$ per (minute $\times \mathrm{mm} \mathrm{Hg}$ $X \mathrm{~kg}$ fetus). However, on the basis of diffusing capacity per mass of organ, the placenta is far less efficient. A $70-\mathrm{kg}$ man would have about $600 \mathrm{~g}$ of lung parenchymal tissue (37), giving a diffusing capacity of $50 \mathrm{ml}$ per (minute $\times \mathrm{mm}$ $\mathrm{Hg} \times \mathrm{kg}$ lung tissue), but the 500-g placenta had a diffusing capacity of only $1 \mathrm{ml}$ per (minute $\times \mathrm{mm} \mathrm{Hg} \times \mathrm{kg}$ of placental tissue).

Control values of $[\mathrm{COHb}]$ and $\mathrm{PcO}$ during the "steady state." During the control period the $[\mathrm{COHb}]_{M}$ and $[\mathrm{COHb}]_{F}$ in the dogs and sheep were relatively stable, both slowly rising as $\mathrm{CO}$ was produced. The average $[\mathrm{COHb}]_{\mathrm{F}} /$ $[\mathrm{COHb}]_{\mathrm{M}}$ was 3.2 , which is higher than that reported for humans, namely $1.5 \quad(38-40)$. $[\mathrm{COHb}]_{\mathrm{F}}$ for sheep, both during the control period and under assumed steady state conditions after the introduction of $\mathrm{CO}$, is plotted against simultaneous $[\mathrm{COHb}]_{\mathrm{M}}$ in Figure 11. As a first approximation we assumed that Pco in fetal and maternal capillary blood are equal, as is $\mathrm{M}$; then according to the Haldane relation (Equation 3),

$$
\frac{[\mathrm{COHb}]_{\mathrm{F}}}{[\mathrm{COHb}]_{\mathrm{M}}}=\frac{\left[\mathrm{O}_{2} \mathrm{Hb}\right]_{\mathrm{F}} \overline{\mathrm{P}}_{2 \mathrm{M}}}{\left[\mathrm{O}_{2} \mathrm{Hb}\right]_{\mathrm{M}} \overline{\mathrm{P}}_{2 \mathbf{F}}}
$$

The average value of fetal capillary $\mathrm{Po}_{2}\left(\overline{\mathrm{P}} \mathrm{O}_{2 \mathrm{~F}}\right)$ by the Bohr integration technique was $20 \mathrm{~mm}$ $\mathrm{Hg}$, and that of maternal placental capillary $\mathrm{PO}_{2}$ $\left(\overline{\mathrm{P}}_{2 \mathrm{~m}}\right)$ was $52 \mathrm{~mm} \mathrm{Hg}$. Inserting these values in Equation 4, we determined $[\mathrm{COHb}]_{\mathrm{F}}$ as a function of $[\mathrm{COHb}]_{\mathrm{M}}$, and the theoretical line is plotted in Figure 11. The regression equation for the theoretical line is $y=2.13 x$, and that for the experimental data is $y=0.70+2.1 x$. In view of the numerous assumptions the agreement between theoretical and experimental results in the Figure is reasonable, but note that the experimental $[\mathrm{COHb}]_{F}$ is consistently greater than the calculated value of $[\mathrm{COHb}]_{\mathrm{r}}$. This may be due to several factors.

The Pco in the fetal capillary beds will be slightly higher than in the maternal even during steady state due to the $\mathrm{CO}$ produced by the fetus. For example, choosing a hemoglobin mass of 18 


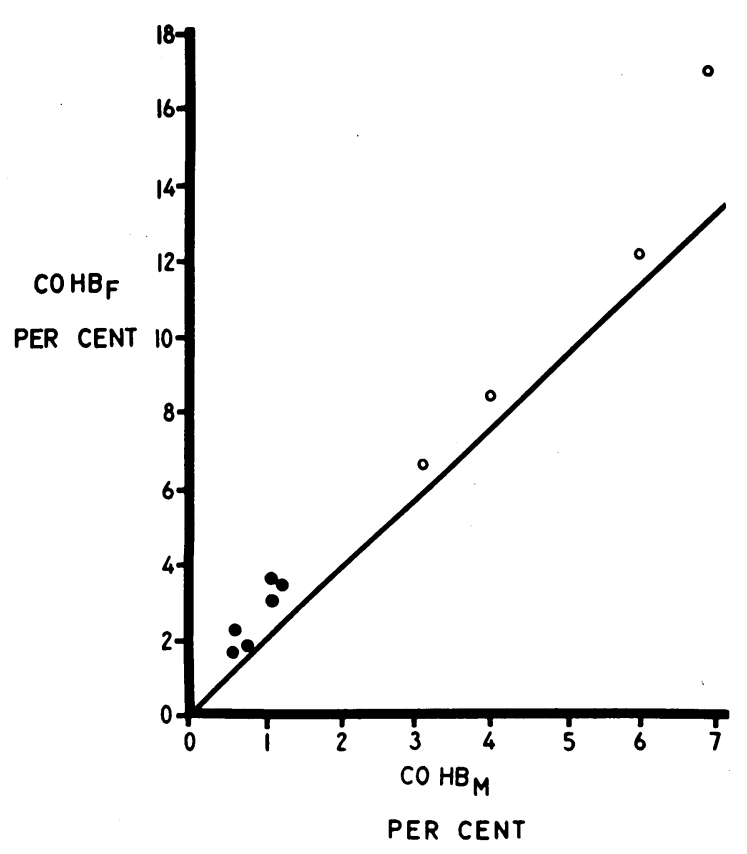

Fig. 11. Relation of Maternal CarboxyhemogloBIN [COHB] M AND FETAL CARBOXYHEMOGLOBIN [COHB] DURING "STEADY STATE" CONDITIONS IN SHEEP. Closed circles represent $[\mathrm{COHb}]$ values during initial control periods. Open circles represent values when equilibrium was approached 9 to 18 hours after the introduction of exogenous $\mathrm{CO}$. The line represents the theoretical relation assuming a mean maternal placental capillary $\mathrm{Po}_{2}$ $\left(\overline{\mathrm{P}}_{2 \mathrm{M}}\right)$ of $52 \mathrm{~mm} \mathrm{Hg}$, a maternal $\mathrm{pH}$ of 7.5 , a mean fetal placental capillary $\mathrm{Po}_{2}\left(\overline{\mathrm{P}}_{\mathrm{O}_{\mathbf{F}}}\right)$ of $20 \mathrm{~mm} \mathrm{Hg}$, and a fetal $\mathrm{pH}$ of 7.2.

g per $100 \mathrm{ml}$ blood (41), an erythrocyte half-life of 19 days (42), and an average of $100 \mathrm{ml}$ blood per kg tissue, we obtain a $\mathrm{CO}$ production of about $1 \times 10^{-4} \mathrm{ml} \mathrm{CO}$ per (minute $\times \mathrm{mm} \mathrm{Hg} \times \mathrm{kg}$ fetal weight). The average diffusing capacity of the placenta was $0.5 \mathrm{ml}$ per (minute $\times \mathrm{mm}$ $\mathrm{Hg} \times \mathrm{kg}$ ) so that the difference in maternal and fetal Pco should be $1 \times 10^{-4} / 0.5=2 \times 10^{-4}$ $\mathrm{mm} \mathrm{Hg}$. This is an order of magnitude less than the measured Pco gradient (Table II).

The value of $M$ may not be the same in fetal and maternal blood. As noted earlier our measurements indicate that there is no marked difference at the same $\mathrm{pH}$; however, since maternal and fetal blood differ by 0.1 to $0.3 \mathrm{pH} U$ this may vary $M$ enough to account for the difference. If incorrect values of blood $\mathrm{pH}$ are assumed, leading to errors in the dissociation curves used, this also may account in part for the discrepancy noted above. In summary we have no complete explanation at this time for the apparent discrepancy in the relationship of $[\mathrm{COHb}]_{\mathrm{F}} /$ $[\mathrm{COHb}]_{\mathrm{M}}$ during the steady state. We believe that the maternal and fetal Pco are nearly equal during a steady state and that the source of this slight discrepancy lies in one of the items listed above or some other factor that we have not considered. We emphasize, however, that this is a rather theoretical point and has little effect on the calculation of the partial pressure gradient after the introduction of $\mathrm{CO}$ or in calculation of CO diffusing capacity.

Placental diffusing capacity for oxygen ( $\left.\mathrm{DP}_{2}\right)$. The placental oxygen diffusing capacity for sheep was first calculated by Barcroft (1). This "diffusion constant" as he called it was approximately $0.08 \mathrm{ml}$ per (minute $\times \mathrm{mm} \mathrm{Hg} \times \mathrm{kg}$ fetal weight) in fetal lambs during the last trimester of pregnancy. For these calculations Barcroft used a previously published $\mathrm{O}_{2}$ consumption $\left(\dot{\mathrm{VO}}_{2}\right)$ of $4.3 \mathrm{ml} \mathrm{O}{ }_{2}$ per (minute $X$ $\mathrm{kg}$ fetal weight) (43). The maternal-fetal $\mathrm{Po}_{2}$ gradient was calculated as the difference between the average of uterine arterial plus venous $\mathrm{PO}_{2}$ less the average of umbilical venous plus arterial $\mathrm{Po}_{2}$. Using the same method, Barron and Alexander (34) and Barron and Meschia (2) calculated a placental "diffusion coefficient" varying from 0.1 to $0.2 \mathrm{ml}$ per (minute $\times \mathrm{mm} \mathrm{Hg}$ $\times \mathrm{kg}$ fetal weight). Bartels and Moll (4), using independent techniques, arrived at essentially the same figure, $0.17 \mathrm{ml}$ per (minute $\times \mathrm{mm} \mathrm{Hg}$ $\times \mathrm{kg}$ ).

Evidence is accumulating, however, that the $\mathrm{DP}_{\mathrm{O}_{2}}$ is probably valueless as a measure of placental exchange: 1) Placental $\mathrm{O}_{2}$ consumption is from one-tenth to one-third of the total placental $\mathrm{O}_{2}$ exchange $(5,6)$. Although the fetal $\mathrm{O}_{2}$ uptake might be calculated from the umbilical arteriovenous difference $X$ blood flow, permitting an estimate of placental and uterine $\mathrm{O}_{2}$ consumption as the difference of total placental exchange and fetal consumption, we do not know where this $\mathrm{O}_{2}$ consumed by the placental tissue is removed from the blood in relation to the site of $\mathrm{O}_{2}$ exchange across the capillaries. If even a small portion of it leaves the blood after the blood has exchanged with the maternal capillaries, the venous outflow $\mathrm{Po}_{2}$ will differ from the proper end capillary $\mathrm{Po}_{2}$ required for any 
diffusion calculations. 2) Anatomical shunts or uneven distribution of maternal placental flow, $\dot{Q}_{M}$, and fetal placental flow, $\dot{Q}_{F}$, will also result in gross errors in the estimate of the end capillary $\mathrm{PO}_{2}$ from measurement of the $\mathrm{Po}_{2}$ in the uterine and umbilical veins (7). This is because in regions of the placenta with high fetal blood flow but low maternal flow, the fetal end capillary $\mathrm{PO}_{2}$ will be relatively low. In other compartments with relatively low fetal and high maternal flows, the end capillary $\mathrm{Po}_{2}$ will be higher. $\mathrm{A}$ mixture of blood from these two regions will have a $\mathrm{PO}_{2}$ less than the average of the two end capillary $\mathrm{Po}_{2}$ because this mixture will have a greater contribution from the compartment with the lower $\mathrm{Po}_{2}$. Nonuniform placental blood flow is not merely a minor theoretical objection. Small anatomic shunts in the fetal vessels of the human placenta have been reported by several workers $(44,45)$. Our own studies in sheep of the distribution of maternal and fetal placental blood flow using macroaggregates of albumin, MAA*, labeled with $^{125}$ I and ${ }^{131}$ I, show gross nonuniform distribution of placental blood flow. Approximately one-fourth of the total placental weight receives less than one-twentieth of the total blood flow (7). In further studies of $\mathrm{O}_{2}$ exchange at hyperbaric pressures in sheep, the uterine vein-umbilical vein $\mathrm{O}_{2}$ difference of about 700 $\mathrm{mm} \mathrm{Hg}$ is evidence for about $30 \%$ physiologic shunt on either the maternal or fetal side of the placenta (46). Such a degree of shunting of umbilical flow has also been demonstrated in a sheep placenta perfused with dextran containing dissolved CO (47). Thus as a result of both placental oxygen consumption and of uneven distribution of blood flow, the $\mathrm{Po}_{2}$ values in the uterine and umbilical veins will have an as yet undetermined relation to the values of $\mathrm{Po}_{2}$ in the end capillaries. 3) In addition, there is considerable uncertainty as to the geometric arrangement of the maternal and fetal placental capillaries. Although in sheep a countercurrent relationship has been reported (48), there is no physiologic evidence for this $(46,47)$. It is thus apparent from consideration of these three problems that determination of the mean maternal and fetal values of capillary $\mathrm{PO}_{2}$ from uterine and umbilical blood samples by the Lamport modification (49) of the Bohr integration (8) or by any other technique is extremely difficult if not impossible and that it is highly unlikely that $\mathrm{DP}_{\mathrm{O}_{2}}$ can be calculated with any degree of accuracy.

If for the moment one accepts the values of $\mathrm{DP}_{\mathrm{CO}}$ presented in this paper, and assumes that $\mathrm{DP}_{\mathrm{O}_{2}}$ is equal, whereas theory indicates that it must be from 1.2 to 2 times greater (see below), then the end capillary $\mathrm{Po}_{2}$ gradient will be $1 \mathrm{~mm}$ $\mathrm{Hg}$. It is obvious that a gradient of that size cannot be measured experimentally with any acceptable accuracy, particularly in view of the sources of error discussed above, and that therefore the $\mathrm{DP}_{\mathrm{O}_{2}}$ cannot be calculated with any acceptable accuracy. For example, an error in end capillary $\mathrm{Po}_{2}$ of only $0.5 \mathrm{~mm} \mathrm{Hg}$ would result in a $100 \%$ error in the calculation of $\mathrm{DP}_{2}$.

The effect of shunting on the values of $\mathrm{DP}_{2}$ and $\mathrm{DP}_{\mathrm{CO}}$ calculated from umbilical and uterine arterial and mixed venous blood samples is shown in Figure 12. In this Figure is presented the dilemma that faces the investigator who can measure uterine and umbilical arterial and venous $\mathrm{O}_{2} \mathrm{Hb}, \mathrm{CO}, \mathrm{Po}_{2}$, and $\mathrm{pH}$ but who does not know how much shunt exists. Uneven distribution of capillary blood flow is considered as a true shunt, equal on both sides. The calculations are made assuming typical values for the pertinent data as described in the legend of Figure 12. The value of DP is that which must exist for the corresponding value of shunt. For example if there is $20 \%$ shunting and the investigator assumes there is none, he would calculate $\mathrm{DP}_{2}$ of $0.42 \mathrm{ml}$ per (minute $\times \mathrm{mm} \mathrm{Hg}$ ), $62 \%$ of the correct value, 0.68. The corresponding error in $\mathrm{DP}_{\mathrm{CO}}$, however, is only $6 \%$. As the shunt increases, the error in calculated $\mathrm{DP}_{2}$ increases at a much more rapid rate, approaching infinity at a shunt of $26 \%$, because for this value, all of the maternalfetal mean $\mathrm{Po}_{2}$ gradient can be explained by shunt alone. The smaller effect of shunting on the calculated DPco results from the following facts: 1) Exchange of $\mathrm{CO}$ is limited by diffusion and not by blood flow, and fetal Pco will not approach equilibrium with maternal $\mathrm{PCO}$ at any value of shunt. 2) The ratio $\mathrm{Po}_{2} /\left[\mathrm{O}_{2} \mathrm{Hb}\right]$ upon which Pco depends is much more constant over the physiological range than $\mathrm{Po}_{2}$ so that mixing of end capillary blood with shunted blood will have a minimal effect on the mean value of the ratio 


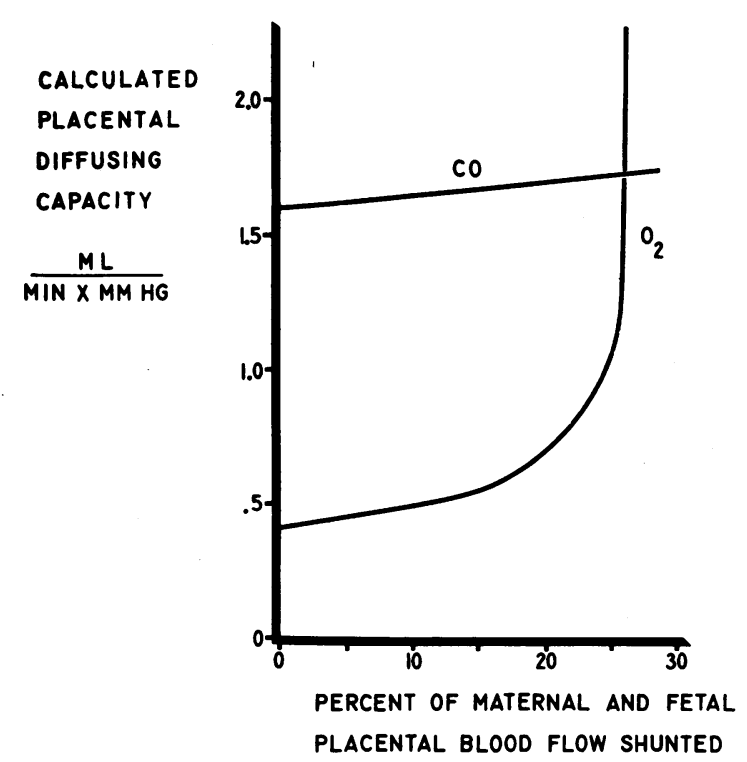

Fig. 12. THE EFFECT OF ARTERIOVENOUS SHUNTS ON THE MATERNAL AND FETAL SIDES OF THE PLACENTAL CAPILLARY BED UPON THE CALCULATION OF $\mathrm{DP}_{\mathrm{CO}}$ AND $\mathrm{DP}_{\mathrm{O}_{2}}$. The abscissa is the percentage of the total blood flow through the maternal and fetal placental circulations that is shunted, this percentage being the same for the maternal and fetal circulations. The ordinate is the value of the $\mathrm{CO}$ and $\mathrm{O}_{2}$ diffusing capacities of the placenta (DPco and $\mathrm{DP}_{\mathrm{O}_{2}}$ ) that would be calculated assuming the following constant values: per cent $\mathrm{O}_{2} \mathrm{Hb}$ in uterine artery $=96.5 \%$, in uterine vein $=66 \%$, in umbilical artery $=15 \%$, in umbilical vein $=69 \%$; maternal $\mathrm{pH}=7.5$ and fetal $\mathrm{pH}=7.2$; hemoglobin $\mathrm{O}_{2}$ capacity $=0.15 \mathrm{ml}$ per $\mathrm{ml}$; oxyhemoglobin dissociation curves of Meschia and co-workers (20); concurrent capillary blood flow; fetal $\mathrm{O}_{2}$ consumption $=13$ $\mathrm{ml}$ per minute for a fetus weighing $3 \mathrm{~kg}(41)$; [COHb $]_{\mathrm{M}}$ $=5 \%$ and $[\mathrm{COHb}]_{\mathbf{F}}=2.5 \%$; and fetal $\mathrm{CO}$ uptake $=$ $0.34 \mathrm{ml}$ per minute. These values are typical of the experiments. Each value of diffusing capacity is that which would be calculated by an investigator in possession of the measurable data assumed, if he assumed the corresponding shunt.

$\mathrm{PO}_{2} /\left[\mathrm{O}_{2} \mathrm{Hb}\right]$, and therefore on capillary Pco. 3) The arteriovenous $[\mathrm{COHb}]$ difference is negligible; therefore mixing of end capillary blood with shunted blood will not change the $[\mathrm{COHb}]$.

It is at least theoretically possible to approximate the mean maternal-fetal $\mathrm{Po}_{2}$ gradient by a principle originated by Haldane and Smith (24). If one assumes steady state conditions for $\mathrm{CO}$ exchange (except for the miniscule gradient produced by the production of $\mathrm{CO}$ in the fetus), then the average Pco of both maternal and fetal capil- lary beds should be equal, Equation 4 should apply, and one should be able to calculate average values for $\mathrm{Po}_{2} /\left[\mathrm{O}_{2} \mathrm{Hb}\right]$ on either side of the placenta. $[\mathrm{COHb}]_{\mathrm{F}}$ and $[\mathrm{COHb}]_{\mathrm{M}}$ can be considered equal to the respective values in either arterial or venous blood, since the arteriovenous differences are so small. $\mathrm{Po}_{2} /\left[\mathrm{O}_{2} \mathrm{Hb}\right]_{F}$ and $\mathrm{PO}_{2 \mathrm{M}} /\left[\mathrm{O}_{2} \mathrm{Hb}\right]_{\mathrm{M}}$ should properly be the respective integrals of these ratios, along the capillary, but these cannot be defined without prior knowledge of the course of $\mathrm{PO}_{2}$ along the two capillary beds. When we used the means of arterial and venous values of $\mathrm{Po}_{2}$ and $\mathrm{O}_{2} \mathrm{Hb}$ as the average along the capillary, and experimental data from sheep 9 and 11 obtained after exposure to a constant concentration of inspired $\mathrm{CO}$ for more than 18 hours, we obtained $\mathrm{PO}_{2}$ gradients of 30 to $40 \mathrm{~mm} \mathrm{Hg}$. As noted above, the calculation of equilibrated $\mathrm{P}_{\mathrm{CO}}$ is relatively insensitive to changes in $\mathrm{PO}_{2}$, assuming chemical equilibrium within the blood, and by the same token, the reverse calculation, of $\mathrm{Po}_{2}$ from $\mathrm{PCO}$ is extremely sensitive to changes in the latter. In this Haldane method one is essentially calculating the $\mathrm{PO}_{2}$ from $\mathrm{PcO}$, and the former is not defined within useful limits under the present experimental conditions.

$\mathrm{DP}_{\mathrm{O}_{2}}$ calculated from the $\mathrm{DP}_{\mathrm{CO}}$. The resistance to diffusion results from the sum of the membrane resistance and the resistance of the maternal and fetal placental capillary blood (33) and may be expressed by the equation,

$$
\frac{1}{\mathrm{DP}_{\mathrm{CO}}}=\frac{1}{\theta_{\mathrm{M}} \mathrm{Vc}_{\mathrm{M}}}+\frac{1}{\mathrm{DM}}+\frac{1}{\theta_{\mathrm{M}} \mathrm{Vc}_{\mathrm{F}}},
$$

where $\theta_{\mathrm{M}}$ and $\theta_{\mathrm{F}}$ are the reaction rates of intracellular hemoglobin expressed in milliliters of $\mathrm{CO}$ per minute per millimeter $\mathrm{Hg}$ gradient of partial pressure of dissolved gas between the interior of the red cell and the plasma per milliliter of maternal and fetal blood. $V_{c_{M}}$ is the maternal placental capillary volume in milliliters, $D_{M}$ is the true diffusing capacity of the placental membrane separating the maternal and fetal bloods in milliliters per minute per millimeter $\mathrm{Hg}$, and $\mathrm{Vc}_{\mathrm{F}}$ is the fetal placental capillary volume in milliliters. The derivation of this equation, and a consideration of the relative importance of $D_{M}$ and chemical reaction rates to over-all diffusion, will be considered in a subsequent communication. According to Graham's law and Henry's law, the 
membrane diffusing capacity for $\mathrm{O}_{2}$ should be 1.23 times that for $\mathrm{CO}$ (50). Although values for $\theta$ for $\mathrm{O}_{2}$ and $\mathrm{CO}$ for sheep ery throcytes are not presently available, based on values for human red cells, $\theta$ for $\mathrm{O}_{2}$ is about twice that for $\mathrm{CO}$ using average values for mean capillary $\mathrm{Po}_{2}$ (51). To calculate $\mathrm{DP}_{\mathrm{O}_{2}} / \mathrm{DP}_{\mathrm{CO}}$, one must know the absolute values of $D_{M}$ and $V c$, which are not at present available. However, it is possible to set limits on this ratio. As $\mathrm{D}_{\mathbf{M}} / \theta \mathrm{Vc}$ approaches zero, $\mathrm{DP}_{\mathrm{O}_{2}} / \mathrm{DP}_{\mathrm{CO}}$ would be dependent upon $\theta \mathrm{O}_{2} / \theta \mathrm{CO}$, which would be 2.0. At the other extreme, if $\theta_{\mathrm{M}} \mathrm{Vc}_{\mathrm{M}}$ and $\theta_{\mathrm{F}} \mathrm{Vc}_{\mathrm{F}}$ were negligible, $\mathrm{DP}_{\mathrm{O} 2} / \mathrm{DP}_{\mathrm{CO}}$ would be dependent only upon $\mathrm{DM}_{\mathrm{O}_{2}} / \mathrm{DM}_{\mathrm{Co}}$ and would be 1.23. Since $V c_{M}$ and $V c_{F}$ would be the same for $\mathrm{CO}$ and $\mathrm{O}_{2}$, the true $\mathrm{DP}_{\mathrm{O}_{2}}$ should be from 1.2 to 2 times the $D_{P_{C O}}$ or 0.65 to $1.1 \mathrm{ml}$ per (minute $\times \mathrm{mm} \mathrm{Hg} \times \mathrm{kg}$ ), depending on the relative contribution to $\mathrm{DM}$ and $\theta \mathrm{Vc}$ to the DP. Thus the true value of $\mathrm{DP}_{\mathrm{O}_{2}}$ is probably even larger than the $\mathrm{DP}_{\mathrm{CO}}$, and the $\mathrm{Po}_{2}$ end capillary gradient is less than $0.5 \mathrm{~mm} \mathrm{Hg}$. Under these circumstances the end capillary gradient would be too small to measure, and as noted above, it would be impossible to calculate the true $\mathrm{DP}_{\mathrm{O}_{2}}$.

\section{Appendix}

Demonstration that the diffusing capacity of the placenta (DP) is theoretically the same whether diffusion occurs from mother to fetus or in the reverse direction

According to Equation 5 the diffusing capacity from mother to fetus may be expressed:

$$
\underset{\mathrm{DP}}{\longrightarrow}=\frac{1}{\theta_{\mathrm{M} \mathrm{C}_{\mathrm{M}}}}+\frac{1}{\longrightarrow}+\stackrel{\frac{1}{\mathrm{DM}}}{\longrightarrow}
$$

The subscript arrows from left to right indicate that diffusion is occurring from mother to fetus.

Similarly DP from fetus to mother may be expressed as:

$$
\frac{1}{\mathrm{DP}_{\mathrm{P}}}=\frac{1}{\theta_{\mathrm{M}} \mathrm{Vc}_{\mathrm{M}}}+\frac{1}{\longleftarrow}+\frac{1}{\mathrm{DM}^{-}},
$$

where the subscript arrows from right to left indicate that diffusion is occurring from fetus to mother.

Diffusion in liquids is generally isotropic (52); thus $\mathrm{D}_{\mathrm{M}}$

equals $\underset{D_{M}}{\longleftarrow} \quad V c_{M}$ and $V c_{F}$ are the same regardless of the direction of diffusion. Therefore any difference between DP and DP must lie in the differences between $\theta$ and $\theta$.

Theoretically the initial rate of change of $[\mathrm{COHb}]$ inside an infinite layer of hemoglobin solution immediately after the $[\mathrm{CO}]$ at the surface is changed instantaneously may be expressed as [see Equation 3, (51)]:

$$
\frac{\mathrm{d}[\mathrm{COHb}]}{\mathrm{dt}}=\left(1^{\prime}[\mathrm{CO}]_{\mathrm{s}}[\mathrm{Hb}]-1[\mathrm{COHb}]\right) \frac{\tanh \omega}{\omega},
$$

where $[\mathrm{COHb}],[\mathrm{CO}]_{s}$, and $[\mathrm{Hb}]$ are the concentrations of carboxyhemoglobin, carbon monoxide, and reduced hemoglobin, respectively, in the surface layer, in milliliters per milliliter of solution; $t$ is time in seconds; $1^{\prime}$ is the reaction velocity constant for the formation of $\mathrm{COHb}$ in (milliliters per milliliter $)^{-1}$ second $^{-1} ; 1$ is the reaction velocity constant for the dissociation of $\mathrm{COHb}$ in second $^{-1}$; and $\omega=b \sqrt{\left(1^{\prime}[\mathrm{Hb}]\right)} / \mathrm{D}$, where $\mathrm{b}$ is the half thickness of the hemoglobin layer in centimeters, and $\mathrm{D}$ is the diffusion coefficient of $\mathrm{CO}$ in the layer of hemoglobin solution in square centimeters per second. The term $1^{\prime}[\mathrm{CO}]_{8}[\mathrm{Hb}]$ represents the mean rate of formation of $\mathrm{COHb}$ inside the layer, $[\mathrm{Hb}]$ refers to the reduced hemoglobin concentration inside the layer, and $[\mathrm{CO}]_{\mathrm{s}}$ refers to the concentration of dissolved CO outside the layer. (Tanh $\omega$ ) $/ \omega$ is essentially a correction factor to give the average [CO] inside the layer after the start of the process. If the exchange takes place in homogeneous solutions, that is, if diffusion is not involved, $(\tanh \omega) / \omega$ becomes unity. The term $1[\mathrm{COHb}]$ is the rate of dissociation of COHb. This equation is equally true whether there is a decrease or an increase in [COHb].

Although Equation 8 describes the initial stages of $\mathrm{CO}$ exchange in an infinite sheet of hemoglobin solution without a membrane, similar equations can be derived for a sphere, and the effect of diffusion resistance through a membrane can be included. These equations turn out to be similar to Equation 8, except that the correction term, $(\tanh \omega) / \omega$, is different, although still a simple function of the diffusion coefficient, [Hb], dimensions of the membrane, and the association reaction velocity constant $1^{\prime}$. Therefore Equation 8 can be used to describe the CO exchange of red cells, since for our present purposes, the correction factor does not enter in.

$\theta$ is defined as the rate of change of $[\mathrm{COHb}]$, in units of milliliters of gas per (milliliter fluid $\times$ minute $\times$ millimeters $\mathrm{Hg} \Delta \mathrm{PCO})(51)$, and in terms of $(\mathrm{d}[\mathrm{COHb}]) / \mathrm{dt}$ can be expressed as

$$
\theta=\frac{\mathrm{d}[\mathrm{COHb}]}{\mathrm{dt}} \frac{60}{\text { capacity }} \frac{1}{\mathrm{PCO}_{\mathrm{s}}-\mathrm{PCO}_{\mathrm{i}}},
$$

where capacity is the concentration of $\mathrm{CO}$ that could be bound by all forms of hemoglobin present in milliliters per milliliter. $\mathrm{PCO}_{\mathrm{B}}$ is the partial pressure of $\mathrm{CO}$ in millimeters $\mathrm{Hg}$ at the surface of the hemoglobin layer, and $\mathrm{PCO}_{\mathbf{i}}$ is the average value within this layer.

$$
\mathrm{PCO}_{\mathrm{s}}=\frac{[\mathrm{CO}]_{\mathrm{s}}}{\alpha_{\mathrm{s}}},
$$

where $\alpha_{\mathrm{s}}$ is the solubility of CO in the fluid just outside the hemoglobin layer in milliliters per (milliliter $\times$ millimeters $\mathrm{Hg}$ ). 
If there is any $\mathrm{COHb}$ in the hemoglobin layer, it has an associated $\mathrm{PcO}_{\mathrm{i}}$ as follows:

$$
\mathrm{PcO}_{\mathrm{i}}=\frac{1[\mathrm{COHb}]}{1^{\prime}[\mathrm{Hb}] \alpha_{\mathrm{i}}},
$$

where $\alpha_{\mathrm{i}}$ is the solubility of $\mathrm{CO}$ in the layer in milliliters per (milliliter $\times$ millimeters $\mathrm{Hg}$ ). If we substitute Equations 8, 10, and 11 into Equation 9:

$$
\theta=\frac{1^{\prime}[\mathrm{CO}]_{s}[\mathrm{Hb}]-1[\mathrm{COHb}]}{\frac{[\mathrm{CO}]_{\mathrm{s}}}{\alpha_{s}^{\prime}}-\frac{1[\mathrm{COHb}]}{1^{\prime}[\mathrm{Hb}] \alpha_{\mathrm{i}}}} \frac{60}{\text { capacity }} \frac{\tanh \omega}{\omega} .
$$

If $\alpha_{\mathrm{B}}$ is assumed to equal $\alpha_{\mathrm{i}}$, which is experimentally justified (53), this becomes

$$
\theta=\alpha_{\mathrm{s}} \frac{1^{\prime}[\mathrm{Hb}] 60}{\text { capacity }} \frac{\tanh \omega}{\omega} .
$$

The value of $\theta$ is independent of the direction of the diffusion flow and therefore DP is independent of the direction of flow.

The fact that only $1^{\prime}$ appears in Equation 13 might lead the reader to conclude that this applies only to the association of $\mathrm{CO}$ with $\mathrm{Hb}$, but this is not the case. To calculate $\theta$ one must always compute an equilibrium constant for the reaction of $\mathrm{CO}$ and $\mathrm{Hb}$, which is the ratio of the dissociation to association reaction velocity constants. Therefore Equation 13 contains implicitly the ratio $1 / 1^{\prime}$ and explicitly $1^{\prime}$; in other words both the association and dissociation reaction velocities are involved.

The presence of $\mathrm{O}_{2}$ will alter the kinetics first by reducing the concentration of reduced hemoglobin at any time, and second this in turn will alter $1^{\prime}$, because this constant depends on the number of ligands already bound to a given hemoglobin molecule (53). Although the inclusion of $\mathrm{O}_{2}$ kinetics would render the mathematics difficult to solve, in general it is permissible to assume that the $\mathrm{O}_{2}$ reactions, which are faster than those of $\mathrm{CO}$, are in equilibrium. Thus a finite $\mathrm{O}_{2}$ would merely alter $[\mathrm{Hb}]$ and $1^{\prime}$ by fixed amounts, but would not make $\theta$ in Equation 13 dependent on the direction of diffusion flow.

Equation 8, and therefore the succeeding relations, only apply to the early part of the reaction of $\mathrm{CO}$ with intracellular $\mathrm{Hb}$ when the concentrations of $\mathrm{Hb}$ and $\mathrm{COHb}$ are uniform throughout the layer. This is an important restriction, but unfortunately analytical solutions of the diffusion plus chemical reaction equations cannot be obtained without it. However, all values of $\theta$ obtained experimentally are subject to the same limitation, and at least the data are consistent.

Although we believe it is very clear that theoretically DP should be the same for diffusion flow in either direction across the placenta, there is little actual experimental evidence to support this. We are not aware of any observations of $\theta \mathrm{co}$ made during dissociation; the existing measurements were made during association reactions (51). However, $\theta$ for $\mathrm{O}_{2}$ is not significantly different whether measured during the uptake or loss of $\mathrm{O}_{2}$ by cells in suspensions $(54,55)$. The two measurements of DP from fetus to mother in this paper were the same as those from mother to fetus. Equation 5 also applies to diffusing capacity in the lungs (DL), if one of the $1 / \theta$ Vc terms is deleted, so that any information about the reversibility of DL would contribute to this discussion. Jones, Ellicott, Cadigan, and Gaensler (56) have published data on the increase in alveolar Pco during breath holding, when the blood contains a large concentration of $\mathrm{COHb}$, which can be used to calculate DL from blood to gas. Taking the rise in alveolar Pco from 5 to 20 seconds in their Figure 2 and assuming that the alveolar volume was $5 \mathrm{~L}$, we obtain a DL of $31 \mathrm{ml}$ per (minute $\times \mathrm{mm} \mathrm{Hg}$ ). This is a normal value, certainly not strikingly different from DL measured from gas to blood.

\section{Acknowledgments}

We wish to express our appreciation to Mr. I. Nagelberg, Mrs. M. Friedman, and Mrs. B. Florey for technical assistance in the blood gas determinations, to Dr. C. J. Lambertsen for use of the closed chamber, and to Dr. R. F. Coburn for use of the infrared $\mathrm{CO}$ analyzer.

\section{References}

1. Barcroft, J. Researches on Pre-Natal Life. Springfield, Ill., Charles C Thomas, 1947, vol. 1.

2. Barron, D. H., and G. Meschia. A comparative study of the exchange of the respiratory gases across the placenta. Cold Spr. Harb. Symp. quant. Biol. 1954, 19, 93.

3. Bartels, H., W. Moll, and J. Metcalfe. Physiology of gas exchange in the human placenta. Amer. J. Obstet. Gynec. 1962, 84, 1714.

4. Bartels, H., and W. Moll. Passage of inert substances and oxygen in the human placenta. Pflügers Arch. ges. Physiol. 1964, 280, 165.

5. Friedman, E. A., W. A. Little, and M. R. Sachtleben. Placental oxygen consumption in vitro. II. Total uptake as an index of placental function. Amer. J. Obstet. Gynec. 1962, 84, 561.

6. Campbell, A. G. M., G. S. Dawes, A. P. Fishman, A. I. Hyman, and G. B. James. The oxygen consumption of the placenta and foetal membranes in the sheep. J. Physiol. (Lond.) 1966, 182, 439.

7. Power, G. G., L. D. Longo, H. N. Wagner, Jr., D. E. Kuhl, and R. E. Forster. Distribution of blood flow to the maternal and fetal portions of the sheep placenta using macroaggregates (abstract). J. clin. Invest. 1966, 45, 1058.

8. Bohr, C. Über die spezifische Tätigkeit der Lungen bei der respiratorischen Gasaufnahme und ihr Verhalten zu der durch die Alveolarwand stattfinenden den Gasdiffusion. Skand. Arch. Physiol. 1909, 22, 221.

9. Bohr, C. Über die Bestimmung der Gasdiffusion durch die Lunge und ihre Grösse bei Ruhe und Arbeit. Zbl. Physiol. 1909, 23, 374.

10. Krogh, A., and M. Krogh. On the rate of diffusion of carbonic oxide into the lungs of man. Skand. Arch. Physiol. 1909-1910, 23, 236. 
11. Balthazard, V., and M. Nicloux. Coefficient d'empoisonnement dans l'intoxication mortelle oxycarbonique chez l'homme. Arch. int. Med. Leg. Brux. 1911, 2, 230.

12. Nicloux, M. Méchanisme du passage de l'oxyde de carbone de la mère au foetus et des respirations placentaire et tissulaire. Arch. mens. Obstét. 1913, $3,42$.

13. Curtis, G. W., E. J. Algeri, A. J. McBay, and R. Ford. The transplacental diffusion of carbon monoxide. A review and experimental study. Arch. Path. 1955, 59, 677.

14. Friberg, L., A. Nyström, and H. Swanberg. Transplacental diffusion of carbon monoxide in human subjects. Acta physiol. scand. 1959, 45, 363.

15. Meschia, G., J. R. Cotter, C. S. Breathnach, and D. H. Barron. The hemoglobin, oxygen, carbon dioxide and hydrogen ion concentrations in the umbilical bloods of sheep and goats as sampled via indwelling plastic catheters. Quart. J. exp. Physiol. 1965, 50, 185.

16. Van Slyke, D. D., and J. M. Neill. The determination of gases in blood and other solutions by vacuum extraction and manometric measurement. I. J. biol. Chem. 1924, 61, 523.

17. Drabkin, D. L., and J. H. Austin. Spectrophotometric studies. V. A. technique for the analysis of undiluted blood and concentrated hemoglobin solutions. J. biol. Chem. 1935, 112, 105.

18. Coburn, R. F., G. K. Danielson, W. S. Blakemore, and R. E. Forster II. Carbon monoxide in blood: analytical method and sources of error. J. appl. Physiol. 1964, 19, 510.

19. Dill, D. B., H. T. Edwards, M. Florkin, and R. W. Campbell. Properties of dog blood. J. biol. Chem. 1932, 95, 143.

20. Meschia, G., A. Hellegers, J. N. Blechner, A. S. Wolkoff, and D. H. Barron. A comparison of the oxygen dissociation curves of the bloods of maternal, fetal and newborn sheep at various pHs. Quart. J. exp. Physiol. 1961, 46, 95.

21. Dittmer, D. S., and R. M. Grebe, Eds. Handbook of Respiration, W.A.D.C. Technical Report 58-352. Wright Air Development Center, Air Research and Development Command, U. S. Air Force, WrightPatterson Air Force Base, Ohio, 1958.

22. Haldane, J. B. S. The dissociation of oxyhaemoglobin in human blood during partial $\mathrm{CO}$ poisoning (abstract). J. Physiol. (Lond.) 1912-1913, 45, xxii.

23. Roughton, F. J. W., and R. C. Darling. The effect of carbon monoxide on the oxyhemoglobin dissociation curve. Amer. J. Physiol. 1944, 141, 17.

24. Haldane, J., and J. L. Smith. The absorption of oxygen by the lungs. J. Physiol. (Lond.) 1897, 22, 231.

25. Paul, W., and F. J. W. Roughton. The equilibrium between oxygen and sheep haemoglobin at very low percentage saturation. J. Physiol. (Lond.) 1951, 113, 23.
26. Roughton, F. J. W. The equilibrium between carbon monoxide and sheep haemoglobin at very high percentage saturations. J. Physiol. (Lond.) 1954, 126, 359.

27. Allen, T. A., and W. S. Root. Partition of carbon monoxide and oxygen between air and whole blood of rats, dogs and men as affected by plasma $\mathrm{pH}$. J. appl. Physiol. 1957, 10, 186.

28. Coburn, R. F., W. S. Blakemore, and R. E. Forster. Endogenous carbon monoxide production in man. J. clin. Invest. 1963, 42, 1172.

29. Coburn, R. F., W. J. Williams, P. White, and S. B. Kahn. The production of carbon monoxide from hemoglobin in vivo. J. clin. Invest. 1967, 46, 346.

30. Wise, C. D., and D. L. Drabkin. Enzymatic degradation of hemoglobin and hemin to biliverdin and carbon monoxide. Fed. Proc. 1965, 24, 222.

31. Killick, E. M. Carbon monoxide anoxemia. Physiol. Rev. 1940, 20, 313.

32. Handbook of Chemistry and Physics, 45th ed. Cleveland, Chemical Rubber Co., 1964.

33. Roughton, F. J. W., and R. E. Forster. Relative importance of diffusion and chemical reaction rates in determining rate of exchange of gases in the human lung, with special reference to true diffusing capacity of pulmonary membrane and volume of blood in the lung capillaries. J. appl. Physiol. 1957, 11, 290.

34. Barron, D. H., and G. Alexander. Supplementary observations on the oxygen pressure gradient between the maternal and fetal bloods of sheep. Yale J. Biol. Med. 1952, 25, 61.

35. Wimsatt, W. A. Some aspects of the comparative anatomy of the mammalian placenta. Amer. J. Obstet. Gynec. 1962, 84, 1568.

36. Ludwig, K. S. Zur Feinstruktur der materno-fetalen Verbindung im Placentom des Schafes (Ovis aries L). Experientia (Basel) 1962, 18, 212.

37. Cander, L., and R. E. Forster. Determination of pulmonary parenchymal tissue volume and pulmonary capillary blood flow in man. J. appl. Physiol. 1959, 14, 541.

38. Gemzell, C. A., H. Robbe, and G. Strøm. On the equilibration of carbon monoxide between human maternal and fetal circulation in vivo. Scand. J. clin. Lab. Invest. 1958, 10, 372.

39. Haddon, W., Jr., R. E. L. Nesbitt, and R. Garcia. Smoking and pregnancy: carbon monoxide in blood during gestation and at term. Obstet. and Gynec. 1961, 18, 262.

40. Young, I. M., and L. G. C. E. Pugh. The carbon monoxide content of foetal and maternal blood. J. Obstet. Gynaec. Brit. Cwlth 1963, 70, 681.

41. Smith, C. Physiology of the Newborn Infant, 3rd ed. Springfield, Ill., Charles C Thomas, 1959.

42. Hollingsworth, J. W. Lifespan of fetal erythrocytes. J. Lab. clin. Med. 1955, 45, 469.

43. Barcroft, J., J. A. Kennedy, and M. F. Mason. The direct determination of the oxygen consumption of the foetal sheep. J. Physiol. (Lond.) 1939, 95, 269. 
44. Bфe, F. Vascular morphology of the human placenta. Cold Spr. Harb. Symp. quant. Biol. 1954, 19, 29.

45. Danesimo, V. Dispositivi di bloccoed anastomosi artero-venose nei vasi fetali della placenta umana. Arch. Ostet. Ginec. 1950, 55, 251.

46. Longo, L. D., G. G. Power, and R. E. Forster II. Placental exchange of carbon monoxide at hyperbaric pressures (abstract). Physiologist 1966, 9, 233.

47. Metcalfe, J., W. Moll, H. Bartels, P. Hilpert, and J. T. Parer. Transfer of carbon monoxide and nitrous oxide in the artificially perfused sheep placenta. Clin. Res. 1965, 16, 95.

48. Barcroft, J., and D. H. Barron. Observations upon the form and relations of the maternal and fetal vessels in the placenta of the sheep. Anat. Rec. 1946, 94, 569.

49. Lamport, $H$. The transport of oxygen in the sheep's placenta: the diffusion constant of the placenta. Yale J. Biol. Med. 1954-1955, 27, 26.

50. Comroe, J. H., R. E. Forster II, A. B. DuBois, W. A. Briscoe, and E. Carlsen. The Lung. Clinical Physiology and Pulmonary Function Tests, 2nd ed. Chicago, Year Book, 1962.
51. Forster, R. E. Rate of gas uptake by red cells in Handbook of Physiology, Section 3, Respiration. Washington, D. C., American Physiological Society, 1964, vol. 1 .

52. Jost, W. Diffusion in Solids, Liquids, Gases. New York, Academic Press, 1952.

53. Roughton, F. J. W. Transport of oxygen and carbon dioxide in Handbook of Physiology, Section 3, Respiration. Washington, D. C., American Physiological Society, 1964, vol. 1.

54. Lawson, W. H., Jr., R. A. B. Holland, and R. E. Forster. Effect of temperature on deoxygenation rate of human red cells. J. appl. Physiol. 1965, 20, 912.

55. Staub, N. C., J. M. Bishop, and R. E. Forster. Importance of diffusion and chemical reaction rates in $\mathrm{O}_{2}$ uptake in the lung. J. appl. Physiol. 1962, 17, 21.

56. Jones, R. H., M. F. Ellicott, J. B. Cadigan, and E. A. Gaensler. The relationship between alveolar and blood carbon monoxide concentrations during breathholding. Simple estimation of $\mathrm{COHb}$ saturation. J. Lab. clin. Med. 1958, 51, 553. 